\title{
MAROSVÁRi ATtILA
}

marosvari@vnet.hu

történész (Makó)

\section{A nemzeti bizottságok Makón az 1956-os forradalom idején}

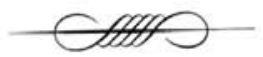

\begin{abstract}
This study investigates the circumstances of the formation and short existence of the town and district national committees, and the main measures taken by them in Makó, in the days of the 1956 revolution. These committees were formed on the basis of a popular front union, to replace the party-ruled council organizations. Although it was clear that the ruling party (MDP) wanted to preserve its power, this proved partially unsuccessful, as the electors thwarted the election of the communists. The leaders and members of the committees were unable to form a radical programme, because of the influence of the social democrats and the small-holders, and the very short time before the Soviet intervention. There were no radical local actions either, which could have caused real changes in the town. Thanks to all these, the local representatives of the party-ruled administration - though somewhat demoralized - managed to survive more or less without serious breaks, and could retake their positions.
\end{abstract}

\section{KEYWORDS}

1956 revolution, Makó, national committee

DOI 10.14232/belv.2018.1.6 https://doi.org/10.14232/belv.2018.1.6

Cikkre való hivatkozás / How to cite this article: Marosvári Attila (2018): A nemzeti bizottságok Makón az 1956-os forradalom idején. Belvedere Meridionale vol. 30. no. 1. 77-113. pp.

ISSN 1419-0222 (print) ISSN 2064-5929 (online, pdf)

(Creative Commons) Nevezd meg! - Így add tovább! 4.0 (CC BY-SA 4.0)

(Creative Commons) Attribution-ShareAlike 4.0 International (CC BY-SA 4.0)

www.belvedere-meridionale.hu 
Az 1956-os forradalom első napjainak addig nem tapasztalt, elementáris erejü tömegmozgalma a Rákosi Mátyás nevével fémjelzett és hamar meggyülölt totalitárius rendszertől való megszabadulás vágyából és akaratából táplálkozott. A társadalom túlnyomó többsége így vagy úgy szembekerült a kommunista hatalommal, s a fölhalmozódott indulatok az október 23-ai budapesti eseményeket követő napokban, különösen az október 25-ei Parlament előtti sortüzet követően végigsöpörtek szinte az ország összes településén. A tömegakarat a szovjet mintákat követő önkényuralmi berendezkedés ellen fordult, de hamarosan kérdéssé vált mindenütt, hogy a bukott rendszert milyen berendezkedés váltsa föl, mi legyen az a népképviseleti struktúra, amely helyi szinten a forradalom intézményesülését biztosíthatja. Szinte természetes volt, hogy az 1944-45-ben létrejött nemzeti bizottságok mintájára és egyfajta népfrontos logikát követve szerveződjenek meg 1956 októberének utolsó napjaiban a települések új néphatalmi fórumai, teret biztosítva az újjáéledő pártok, illetve más akkor megalakult szervezetek és erőcsoportok képviselői számára, hogy „,belakják” ezeket a fórumokat és újjáélesszék településükön a demokratikus hatalomgyakorlás régóta hiányzó formáit.

Jelen tanulmány az 1956-os forradalom makói néphatalmi szerveinek, így a városi, illetve a járási nemzeti bizottság létrejöttének körülményeit, a mögöttes hatalmi szándékok összefüggéseit vizsgálja, számba veszi és elemzi azokat a döntéseket és intézkedéseket, melyeket Makó Város Nemzeti Bizottsága rövidre szabott ténykedése során hozott. ${ }^{1}$

\section{ELŐZMÉNYEK ÉS KÖRÜLMÉNYEK}

A makói forradalmi események - mint általában a magyar vidék településein - a budapesti forradalom kitöréséhez képest több napos fáziskéséssel következtek be. Noha az emberek a rádión keresztül folyamatosan figyelemmel kísérték a legfrissebb híreket, és a Pestről és Szegedről hazaérkezőktől is kaptak és szereztek információkat, az első tömeges megmozdulásra csak október 26-án pénteken került sor. ${ }^{2}$ A forradalmi események két erjesztő centruma ezt megelőzően a gimnázium és a város legnagyobb üzeme, a Makói Gépgyár volt, ahol a legélénkebben reagáltak a fővárosban és a nagyvárosokban, főként a Szegeden lezajló eseményekre. A gimnáziumban már október 25-én diákgyülést tartottak, ahol a tanulók különböző követeléseket hangoztattak, többek között az orosz nyelv tanításának eltörlését szorgalmazták, de ugyanezen a napon a gépgyári munkások is a pesti forradalom melletti demonstrációt - ahogy akkor mondták, röpgyűlést tartottak, ám még szigorúan az üzem falain belül. ${ }^{3}$ Az október 25 -ei parlament előtti sortűz híre - miként a legtöbb helyen az országban - nem csak fölháborította, de radikalizálta is a makóiakat, így az utcai demonstrációkat már nem lehetett semmilyen eszközzel sem megfékezni.

Habár Makó Város Tanácsa VB-elnöke, Földházi Imre egy 1957. április 10-én kelt jelentésében azt állította, hogy a városi tanács végrehajtó bizottsága ,október 23-án müködését kénytelen volt befejezni, illetve felfüggeszteni", ${ }^{4}$ ez csak annyiból volt igaz, hogy tényleges müködésre (ülésre) ez idő alatt valóban nem került sor, de a korábbi hatalmi szervek ténykedésének jogi

\footnotetext{
${ }^{1}$ A november 3-án megalakított járási nemzeti bizottságnál ilyen döntések nem születtek, a bizottság megalakulását követően érdemi munkát már nem végzett.

${ }^{2}$ BÁLINT 2006. 25-30.

${ }^{3}$ ÁBTL 3. 1. 9. V-145872. Fazekas Lajos vizsgálati dossziéja. Fazekas Lajos kihallgatási jkv., 1958. január 22.; JAM TD 75. 181. 1. Följegyzés a Makói Gépgyárban történt eseményekröl; BÁLINT 2006. 23-24.

${ }^{4}$ MNL CSML ML 515. a. Makó Városi Tanács VB. Közösen kezelt iratok. 1763-2/1957. Az októberi ellenforradalmi események hatása a tanácsszervekre. Földházi Imre VB-elnök jelentése. 1.
} 
akadálya nem volt, mivel új hatalmi szerv ekkor még nem jött létre, és a régit sem váltotta le senki. Sőt, a korábbi hatalom különböző szervei továbbra is müködtek, a városi és járási tanácsok dolgozói bejártak munkahelyükre, de még az MDP helyi funkcionáriusai is azt a taktikát követték ezekben a napokban, hogy megpróbálták irányításuk, illetve befolyásuk alatt tartani az eseményeket, ezért megjelentek a különböző rendezvényeken, így a már jelzett gimnáziumi diákgyülésen is. ${ }^{5}$ Katona Sándor országgyülési képviselő is arról írt visszaemlékezésében, hogy október 26-án még képviselői fogadóórát tartott a városi tanács titkári hivatalban, ahol igen sokan megjelentek panaszaikkal. ${ }^{6}$ Mindez arra utal, hogy a hatalmi centrumok müködésében október 26-áig (sőt egyes helyeken még azt követően sem), ha bizonytalanság volt is, de érdemi változás nem történt.

A településeket irányító államhatalmi és államigazgatási szervek működését az 1949-ben elfogadott új, szovjet típusú alkotmány alapján kiadott 1950. évi I. törvény, az ún. első tanácstörvény szabályozta. A törvény nyomán a nagy hagyományú magyar önkormányzati rendszer helyett - szintén szovjet mintára - tanácsokat szerveztek. E tanácsok (megyei, járási, városi és községi tanácsok) az ún. demokratikus centralizmus elve nyomán egymással hierarchikus viszonyban álltak (legfelsőbb szint a minisztertanács volt), amellyel a korábbi önkormányzati rendszer autonómiáját gyakorlatilag teljesen megszüntették és tették centralizálttá, egyúttal ellenőrizhetővé a települések irányítását.

A tanácsok a helyi államhatalom szervei voltak, melyek élén a választott tagokból álló tanácstestületek álltak. Mivel a tanácstestületek csak szükség szerint üléseztek (a városok esetében minimum kéthavonta kellett azokat összehívni), az államhatalom tényleges helyi csúcsszervei a tanácstestületek által tagjaik közül megválasztott, jóval kisebb létszámú, gyakrabban (hetentekéthetente) ülésező és emiatt operatív irányító funkciót ellátó végrehajtó bizottságok (VB-k) voltak, amelyek a két ülés között ellátták a tanácsok feladatait, kivéve azokat, melyeket jogszabály a tanácstestületek kizárólagos kompetenciájába utalt (VB tagjainak megválasztása és visszahívása, a gazdasági terv és a költségvetés elfogadása, bizottságok alakítása stb.). A VB-k első ülésükön tagjaik közül választották meg elnökeiket (VB-elnök), akik egyben a tanácsok elnökei is lettek. A döntési kompetenciáik ellenére is gyakran formális szerepet betöltő tanácsokkal, valamint azok kötelezően létrehozott állandó bizottságaival szemben gyakorlatilag a VB-k voltak azok a szükebb körű irányítási centrumok, ahol a települést érintő tényleges döntések - jelentősebb ügyekben a kommunista állampárt illetékes területi szervezetének előzetes jóváhagyását követően - megszülettek.

A tanácsok alatt - mint tanácsapparátus - müködtek az ún. szakigazgatási szervek, melyek a tanácsi döntések előkészítéséért és végrehajtásáért, továbbá saját igazgatási szakfeladataik ellátásáért voltak felelősek, és egyszerre voltak alárendeltjei a helyi tanácsoknak, illetve saját fölöttes szakigazgatási szerveiknek, így a megyei tanács hasonló osztályainak és végső soron a minisztériumoknak. A szakigazgatási szervek irányításért, valamint a tanácsülések döntéselőkészítő

\footnotetext{
${ }^{5}$ ÁBTL 3. 1. 9. V-145872. Fazekas Lajos vizsgálati dossziéja. Fazekas Lajos kihallgatási jkv., 1958. január 22.; BÁLINT 2006. 24.

${ }^{6}$ KATONA é. n. 117. Katona így írt erről: „,Október 26-án képviselői fogadóórát tartottam Makó városi tanács titkári hivatalában. Nagyon sokan kerestek fel parasztemberek, akiket nem kártalanitottak a termelöszövetkezeti táblák kialakitásakor, több évi keserüségüket mondták el. Határozottan, de nem fenyegetözve próbáltam megnyugtatni öket. Döntö többségük velem egykorú személyes ismerösöm volt. »Több évig káromkodva, fogcsikorgatva kibírtátok a sérelmet, a törvénytelenséget, azt a néhány hetet vagy hónapot ki kell bírnotok, amíg központi kormányintézkedésre megfelelően rendezzük jogos sérelmeiteket. « Látszólag megnyugodva mentek haza; két órakor ért véget a fogadóórám, a városi tanács elnöke [Földházi Imre] arra kért, ha életben maradunk, tartsam meg öt jó emlékezetemben."
} 
tevékenységének koordinálásáért és az ott hozott döntések végrehajtásáért a végrehajtó bizottságok által tagjaik közül megválasztott mindenkori VB-titkárok feleltek. ${ }^{7}$

A tanácsok létszámát lakosságarányosan jogszabály határozta meg. Makón az 1954-es tanácsválasztást követően a tanácstestület létszáma 100 fö, míg a végrehajtó bizottság taglétszáma 13 fő volt. A választást követően a városi tanács végrehajtó bizottságának elnöke Földházi Imre cipészsegéd, helyettese Gera Sándor portás lett, a VB-titkári posztot pedig dr. Karsai András közalkalmazott töltötte be. ${ }^{8}$

Noha a városi tanács fölött formális hatalmat nem gyakorolt, de elvi-ideológiai irányító szerepet folyamatosan ellátott és betöltött a kommunista állampárt, az MDP városi bizottsága, melynek élén ekkor Glemba Pál függetlenített első titkár állt. A tanácsok pártirányításáról az állampárt, a Magyar Dolgozók Pártja (MDP) titkársága még 1950. november 30-án hozott határozatot, amely pontosan megvilágította, mi is volt ez az elvi-ideológiai irányító szerep. Eszerint „A pártszervezetek feladata elvileg irányítani és támogatni a tanácsok munkáját. Szorossá kell tenni a párt és a tanács viszonyát. A párt irányító munkája elsősorban a tanácselnökön keresztül történik. Pártbizottságaink a tanács legfontosabb kérdéseit elözőleg tárgyalják meg az elnökkel." ${ }^{9}$ Ez gyakorlatilag azt jelentette, hogy olyan lényegi döntés, amelyet az illetékes pártbizottság előzetesen ne hagyott volna jóvá, nem kerülhetett a tanács döntéshozó szervei elé. Az átjárást és az átláthatóságot a hatalom számára megkönnyítette, hogy a tanács vezetői általában rendre tagjai voltak az érintett területi pártszervezet vezetőségének, míg a párt helyi vezetői (ha nem is szükségszerűen, bár általában az első számú vezetők) helyet foglaltak a tanács végrehajtó bizottságában. Egy 1953-as makói járási tanácsi VB-jelentés szerint „, $A$ [városi] tanács és VB ülésein a Párt részéről minden alkalommal megjelenik a párttitkár, aki jó hozzászólásával útmutatást ad és segít a tanács és a VB határozatoknál. A VB és a pártszervezet közti kapcsolat jó, [a] fontosabb feladatokat, kormány- és párthatározatokat a városi pártszervezet titkárával megtárgyaljuk, valamint a pártbizottság ülésein a VB elnöke rendszeresen részt vesz." ${ }^{10}$ Ezt állapította meg az akkor végrehajtott ellenőrző vizsgálat jelentése is: „Egyes feladatok végrehatását a végrehajtó bizottság elnöke a városi Pártszervezet titkárával minden esetben átbeszéli, de ugyanakkor a mezögazdasági, oktatási és egyéb vonalon is a városi Pártszervezet segíti a tanács munkáját. Megállapitottuk, hogy a városi tanács munkájában a Pártszervezet irányító szerepe kidomborodik." 11 Ebben változás a következő években sem történt, ezt Szentgyörgyi Zoltán akkori MDP városi első titkár, egyben a városi tanács végrehajtó bizottsága tagja a VB 1956. január 27-ei ülésén a tanács és a végrehajtó bizottság munkáját tárgyaló napirend kapcsán meg is erősítette: „A Pártnak [...] nagy szerepe van a Tanács munkájában, mivel a tanácstagoknak mintegy 50\%-a párttag." 12 Az 1956-os forradalom kitörését megelőzően az MDP Makó városi pártválasztmányának Földházi Imre VB-elnök is tagja volt, ${ }^{13}$ míg a makói városi pártbizottságot a városi tanács végrehajtó

\footnotetext{
7 Mezey 1995. 369-370.; Müller 1988. 11-21., 46-53.; Antal 2009.

${ }^{8}$ Blazovich 2007. 33.; SzentPÉteri 1981. 82., 344-347.

${ }^{9}$ IzSÁK 1998. 128.

${ }^{10}$ MNL CSML ML 202. 4. a. Makói Járási Tanács Végrehajtó Bizottság iratai. VB-ülések jegyzőkönyvei. (járási VB jkv.) Az 1953. február 5-i járási VB. jkv. Makó Város Tanácsa Végrehajtó Bizottsága munkájának kiértékelése.

${ }^{11}$ MNL CSML ML 202. 4. a. Az 1953. febr. 5-i járási VB. jkv. Makó Járási Tanács VB Ellenörzési Csoport vizsgálati jelentése a Makói Városi Tanács munkájáról.

${ }^{12}$ MNL CSML ML 502. a. Makó Városi Tanács Végrehajtó Bizottságának iratai. A Végrehajtó Bizottság jegyzőkönyvei (Makó VB jkv.) Makó VB jkv. 1956. január 27.

${ }^{13}$ Korom 1981. 340.
} 
bizottságában 1956 augusztusáig mint függetlenített első titkár, azt követően - miután pártbizottsági helyére Glemba Pál került - mint pártvezetőségi tag Szentgyörgyi Zoltán képviselte. ${ }^{14}$

A makói forradalom formális kitörésének első, jelképes eseménye a gimnazisták és gépgyári munkások október 26-ai közös fölvonulása és koszorúzási ünnepsége volt a Kossuth-szobornál, ${ }^{15}$ amely még a helyi hatalom által engedélyezett és szervezett formában valósult meg, de néhány óra múlva a fővárosi események miatti elementáris fölháborodás, emellett a személyes sérelmek és a fölgyülemlett rendszerellenes indulatok spontán tömeggé formálták az addig a diákok fölvonulását tétlenül figyelő embereket, és a tömegakarat a gimnázium előtt álló szovjet emlékmű lerombolásával ${ }^{16}$ demonstrálta, szakítani kíván a kommunista diktatúrával, illetve az azt fönntartó szovjet gyámsággal.

Az október 26-át követő napokban a hatalom számára mind ellenőrizhetetlenebbé váló forradalmi események nemcsak elbizonytalanították, de meg is rengették a helyi tanácsi szervek vezetőit és velük együtt a járási és városi pártapparátus funkcionáriusait. Ebben elsődleges szerepe talán nem is a tüntetéseknek vagy a szovjet emlékmü ledöntésének és a vörös csillagok leverésének volt, sokkal inkább annak, hogy az október 27-én reggel elrendelt, s az esti-éjszakai órákra (este 6-tól reggel 5-ig) érvényes kijárási tilalmat ${ }^{17}$ nem lehetett betartatni, mivel a rendőrség, melynek feladata lett volna a rend fenntartása, egy október 27. esti súlyos incidenstől eltekintve (amikor puskatussal verték szét a Kossuth-szobornál gyülekező tömeget) nem fordult szembe (vagy nem volt képes szembefordulni) a demonstrálókkal és napokon át csupán követte az eseményeket. Ebben jelentős szerepe volt Fazekas Lajos rendőr őrnagy, városi rendőrkapitány október 26. utáni elbizonytalanodásának, ${ }^{18}$ aki csak október 28-án tudta megfékezni az előző esti tömegoszlatásért felelősök kiadatása miatt a rendőrség előtt demonstráló tömeget azzal, hogy szóba állva velük elfogadta a skandált (és egyébként abban a helyzetben nem túl radikális, tehát nem is teljesíthetetlen) követeléseket. ${ }^{19}$ Ezzel a gesztusával elejét tudta venni a további

\footnotetext{
${ }^{14}$ Szentgyörgyit 1956 júliusában ugyan leváltották a városi pártbizottság éléről (MNL CSML SZL XXX. MSZMP Archívum. 1. MSZMP Csongrád Megyei Bizottsága iratai. 11. Párt- és tömegszervezeti Osztály iratai. 65. ő. e. Levelek az ellenforradalmi eseményekről. F.10/189/1959. Szentgyörgyi Zoltán. Németh Károly VB elnök és Retkes István megyei fegyelmi referens levele, 1959. szept. 1.), ekkor került helyére a pártiskolát frissen elvégzett Glemba Pál, de a végrehajtó bizottságban betöltött szerepét ez akkor azért nem érintette, mert ott formális választásra nem került sor, e nélkül pedig Glemba itt nem vehette át a helyét. A jelzett gyakorlatot egyébként - mint a pártállami struktúra egyik fontos sarokkövét - a forradalom leverését követően sem változtatták meg. Földházi Imre VB-elnök 1957. december 2-án keltezett jelentésében, amelyet a tanácsok pártirányítása és a községfejlesztési feladatok tárgyában a megyei tanács végrehajtó bizottságához írt, a következők olvashatók (változatlan helyesírással): „, A Városi Tanács és a Pártbizottság között a kölcsönös tájékoztatást egyrészt azon keresztül van meg, hogy a párttitkár tagja a végrehajtóbizottságnak, illetve a VB. elnök tagja a városi Párt Végrehajtóbizottságának. Ezen túlmenően a két vezetö egyébként is megbeszéli a soron lévö egyes feladatok mikénti elintézését, vagy végrehajtását.” MNL CSML ML 515. a. 7425/1957. Földházi Imre VB-elnök jelentése a tanácsok pártirányitása és a községfejlesztési feladatok ügyében. A forradalom leverését követően 1957. márciusában újraválasztott végrehajtó bizottságban a fönti elvnek megfelelően már a városi pártbizottság függetlenített első titkára, Glemba Pál kapott helyett. Elődje, Szentgyörgyi Zoltán ugyan továbbra is tagja maradt a városi tanácsnak, 1957. szeptember 15-én kelt levelében azonban erről a megbízatásáról önként lemondott. MNL CSML ML 515. a. 6068/1957. Szentgyörgyi Zoltán lemondó levele.

${ }^{15}$ Erről bővebben Tо́тн 1992.; То́тн 2006. 123-126.

${ }^{16}$ MARosvÁRI 2006. 3-7.; Az emlékmű ledöntésével kapcsolatban lásd még MNL CSML SZL XXV. 9. Szeged Megyei Bíróság iratai. Büntetőperes iratok (SZMB B.) I. 1214/1957. Kovács Péter és társai pere.

${ }^{17}$ Viharsarok XII. évf. 255. sz. 1956. október 29. 2.

${ }^{18}$ Erről és Fazekas Lajos forradalom idején betöltött szerepéről bővebben lásd MAROsvÁRI 2017.

${ }^{19}$ A megállapodás egy eredeti és aláírt példánya makói József Attila Múzeum állandó várostörténeti kiállításának az 1956-os eseményeket bemutató vitrinjében található (leltári szám nélkül). Fakszimiléje megjelent: Makói História. A József Attila Múzeum lapja. 9. évf. (2006). 2-3. sz. 6. A követelésekről lásd az utóbb „, a népi demokratikus államrend elleni izgatás" vádjával felelősségre vont és elítélt Simon György peranyagát: MNL CSML SZL XXV. 9. SZMB B. I. 1179/1957., továbbá BÁLINT 2006. 42.
} 
spontán tömegtüntetéseknek, s ettől kezdve vissza tudta szerezni az ellenőrzést a város közrendje fölött, de azt megakadályozni már nem volt képes, hogy ne következzék be fordulat a helyi hatalmi szervek szerkezetében és működésében.

Makón a rendőrségen kívül mindössze egy jelentéktelen létszámú, ezért bevetésre teljességgel alkalmatlan fegyveres testület, a Magyar Néphadsereg Makói Járási Kiegészítő Parancsnokság (KIEG) müködött, amely ráadásul - miként Földházi Imre 1957 tavaszán kelt jelentésének tervezetéből is kiderül - , teljes egészben az ellenforradalmárok oldalára állott", ${ }^{20}$ és a pártbizottság fölszólítására sem avatkozott be az eseményekbe (utóbb, a megtorlás idején ezért a felelős tiszteket rang- és állásvesztéssel sújtották). Így tehát a rendőrségen kívül nem volt a városban olyan fegyveres erő, amely szembe mert, vagy szembe akart volna szállni a forradalmi tömegekkel. Szintén demoralizáló következményekkel járt a helyi párt- és tanácsi vezetés számára, hogy október 27-étől sorra alakultak a város üzemeiben a munkástanácsok, a dolgozói önigazgatás szervei, melyek többnyire markánsabb követeléseket és szervezettebb érdekképviseletet mutattak fel, mint az addigi spontánabb kezdeményezések. ${ }^{21}$ A munkástanácsok megalakulása rámutatott arra is, hogy küszöbön állt azoknak a helyi szervezeteknek a létrejötte, amelyek nem csupán üzemi, hanem már városi szinten kívánták kézbe venni az irányítást.

Miközben ennek az új helyi államhatalmi szervnek a megalakítása Szegeden október 25-én megkezdődött (Szeged Város Forradalmi Bizottmánya), majd 29-én lezárult (Szeged Város Néptanácsa), Hódmezővásárhelyen is október 29-én (Hódmezővásárhelyi Nemzeti Bizottság) megtörtént, ${ }^{22}$ addig Makón erre csak október 30-án került sor.

\section{A VÁROSI NEMZETI BIZOTTSÁG LÉTREJÖTTE}

A városi tanács végrehajtó bizottsága forradalom alatti müködésének kevés nyoma maradt meg. Amelyek viszont megmaradtak, azok kizárólag a rend fönntartását célzó intézkedések voltak. Ilyen VB-utasítás fogalmazódott meg október 25-én a Vendéglátóipari Vállalat vezetőjének címzett levélben, amelyben előírták, hogy a város területén működő italboltok csak déli 12 óráig, az éttermek 14 óráig tarthatnak nyitva és amelyben mind az italboltokban, mind pedig a cukrászdákban , további intézkedésig” a szeszárusítást megtiltották. Hasonló utasítást küldtek október 27-én a Vendéglátóipari Vállalat, a Földműves Szövetkezet és a helyi Utasellátó vezetőjének, melyben arról rendelkeztek, hogy „, további intézkedésig az italboltokat azonnali hatállyal le kell zárni”. Ez alól kivételt képezett a Vendéglátóipari Vállalat étterme, ahol kizárólag reggelit, ebédet és vacsorát továbbra is kiszolgálhattak. Mindkét jelzett VB-határozatot Földházi Imre VB-elnök helyett dr. Karsai András VB-titkár írta alá. ${ }^{23}$ Ugyancsak dr. Karsai András volt az, aki október 26-án délután fogadta a Csongrád Megyei Tanács távmondatát, melyben arra hívták föl a helyi tanácsok vezetőjét, hogy ,,azonnal szervezze meg, hogy a hangszórók a községekbe [sic!] mindenhol megszólaljanak a K. V. határozatának [az MDP Központi Vezetősége október 26-ai nyilatkozatáról volt szó - M. A.] ismertetésének ideje alatt”, továbbá fölhívták a tanácselnökök figyelmét, hogy a szesztilalom bevezetésének elrendeléséről saját belátásuk szerint

\footnotetext{
${ }^{20}$ MNL CSML ML 515. a. 1763/1957. Jelentés-tervezet. 4.

${ }^{21}$ BÁlint 2006. 31-32., Marosvári 2008. 145-150.

${ }^{22}$ Délmagyarország XII. évf. 253. sz. 1956. október 30. 1.; Vásárhelyi Nemzeti Újság I. évf. 2. sz. 1956. október 30. 1.; FARKAS 2003. 209., 216-217. ; A nemzeti bizottságok létrejöttének körülményeiről lásd még FARKAS 2006. $100-108$.

${ }^{23}$ MNL CSML ML 503. a. Makó Városi Tanács VB Titkársága iratai. Általános iratok. 13-27/1956.
} 
döntsenek. ${ }^{24}$ Arról, hogy a városi „,hangszórók” közvetítették-e a párt központi vezetőségének nyilatkozatát, nincs információnk, de a föntiekből is jól látható, hogy Földházi ezekben a napokban már operatívan nem vett részt a város irányításában, helyette dr. Karsai András VB-titkár intézkedett, akinek vezetése alatt a tanácsi apparátus ha a körülmények hatására természetszerüleg nem is zökkenőmentesen, de ebben az időszakban is ellátta feladatait. Vélelmezhetően formális VB-döntésekre sem került sor ez idő alatt (jegyzőkönyvek ezt nem támasztják alá), így megalapozottan gondolhatjuk, hogy a VB nevében és jogkörében dr. Karsai András egy személyben járt el a fönti utasítások megfogalmazásakor, bár meglehet, az október 26-ai forradalmi események miatt október 27-én reggel elrendelt (este hattól reggel öt óráig tartó) kijárási tilalomról meghozott döntésben nemcsak a VB-titkár, hanem - a városi pártbizottsággal történt egyeztetést követően - Földházi Imre VB-elnök is közreműködött. ${ }^{25}$ Ennek azonban semmilyen nyoma nem maradt meg a városi tanács iratai között.

A hatalmi vákuum, amelyben a régi településvezetés már nem volt képes érdemben kézben tartani a folyamatokat, az új pedig még nem jött létre, több napig is eltartott. Október 26. és október 30. között gyakorlatilag nem volt kompetens szerv a város élén, annak nevében - mint föntebb láthattuk - néhány formális döntés erejéig dr. Karsai András VB-titkár járt el, a végrehajtó bizottság ugyanis már nem müködött, ülésének összehívására nem került sor. Értelmezhető ez az időszak egyfajta kettős hatalomként is, hiszen ha de facto nem is, de jure még létezett a régi, miközben bizonyos értelemben - a spontán népi akarat formájában funkcionált, formálisan azonban még nem jött létre az új településirányítás. Az exlex helyzetet jól mutatja, hogy ezekben a napokban mindenki Fazekas Lajos rendőrkapitányt kereste problémájával, hiszen - minden bizonytalansága ellenére - az ő egyetértésének és támogatásának éppen a fegyveres erők (rendőrség) féken tartása szempontjából valóságos súlya volt, szemben az erő nélküli politikai szervezetekkel.

Nincs semmilyen adatunk arra vonatkozóan, hogy az új helyi hatalmi szerv létrehozásának kezdeményezése spontán módon és alulról indult volna el. Minden bizonnyal létezett ilyen akarat a tüntetők soraiban, de nem csak hogy források, de érdemi lépések sem ôrizték meg ennek nyomait, miként azt sem, hogy október 28-át megelőzően az MDP funkcionáriusain és aktivistáin kívül az egykori pártok, így a városban az 1948 előtti koalíciós időszakban különösen aktív Szociáldemokrata Párt (SZDP) és Független Kisgazdapárt (FKgP), vagy a Nemzeti Parasztpárt (NPP) egykori szereplői közül bárki kezdeményező szerepet vállalt volna ebben (vagy bármilyen más lépés megtételében) ezekben a napokban. Gyaníthatóan erre nem is került sor. Éppen emiatt hihető és föltételezhetően megalapozott az az állítás, amelyről egyébként B. Papp Mihály akkori VB-elnökhelyettes, országgyülési képviselő beszélt a városi tanács 1957. március 12-ei újjáalakuló ülésén, mely szerint a nemzeti bizottság létrehozására irányuló kezdeményezés az MDP városi pártbizottságától indult ki. ${ }^{26}$ Azért hihető ez, mert a kommunista államhatalmi szervek kádereinek elementáris érdeke volt, hogy ha már nem tudják megakadályozni a régi struktúra széthullását, akkor olyat hozzanak létre, amelyben optimista forgatókönyv esetén a saját kádereiket vezető szerephez tudják juttatni, kevésbé optimista esetben pedig legalább az új szervezet fölötti ellenőrzésüket vagy részleges befolyásukat meg

\footnotetext{
${ }^{24}$ MNL CSML ML 503. a. 10-44/1956.

${ }^{25}$ Viharsarok XII. évf. 255. sz. 1956. október 29. 2.

${ }^{26}$ MNL CSML ML 501. a. Makó Városi Tanács iratai, tanácsülési jegyzőkönyvek. (Makó Tü. jkv.) 1957. március 12. B. Papp Mihály VB-elnökhelyettes beszámolója.; lásd még MNL CSML ML 515. a. 1763/1957. Földházi Imre VB-elnök jelentése.; То́тн 1996. 33., 37.
} 
tudják tartani. ${ }^{27}$ Ehhez a hatalomátmentési stratégiához, amelyet egyébként a megyei pártbizottság már bizonyosan ekkor is ösztönzött, ${ }^{28}$ arra volt szükség, hogy ők maguk álljanak az új népi kezdeményezés élére és olyan partnereket keressenek, akikkel az új hatalmi struktúra arculatának meghatározásában együttmüködést és partnerséget tudnak kialakítani. A saját szerepük átmentésén túl ez azért is fontos volt számukra, hogy meg tudják akadályozni a radikálisabb politikai csoportok esetleges térfoglalását vagy szerepvállalását, amelyek nem pusztán az addigi hatalmi pozícióikat, de személyes biztonságukat is veszélyeztethették volna, ezért egy mérsékeltebb, népfrontos jellegű nemzeti bizottság megalakítása tűnt számukra járható és követendő útnak.

E stratégiai cél konkrét végrehajtását szolgálta a városi MDP bizottság megbízottja, Kalász József által október 28-án kezdeményezett egyeztetés Katona Sándorral, az FKgP volt Csanád megyei titkárával (akkor már az MDP politikáját mindenben kiszolgáló országgyűlési képviselővel) és az egykori SZDP-t képviselő Kiss Ernővel, Zombori Lajossal és Lukács Pállal. A megbeszélésen jelen volt a volt Nemzeti Parasztpárt egy, valamint az ifjúság két meg nem nevezett (ezért nem ismert) képviselője is. Velük megegyeztek egy 11 fős bizottság és egy 30 fős nagybizottság összetételéről, melyek feladata a város irányításának átvétele lett volna. Mivel az egyeztetésről semmiféle följegyzés vagy emlékeztető nem maradt meg, a két bizottság személyi összetételéről sajnos nem rendelkezünk semmilyen érdemi információval, legfőképpen azt nem tudjuk, kik voltak azok a kommunista jelöltek, akiket meg kívántak választatni az új néphatalmi szerv tagjává, miként azt sem tudjuk, hogy abban milyen szerepet szántak volna nekik. ${ }^{29}$ Közvetve mindössze annyi ismeretünk van, hogy Marosi Bálint a József Attila Városi Kultúrház igazgatója bizonyosan szerepelt a javasoltak között (ezt maga árulta el egy későbbi megtorló perben tett tanúvallomásában) és az MDP városi bizottsága ajánlására rajta kívül még hat kommunistát vettek föl a listára. ${ }^{30}$ Minden bizonnyal az MDP tárgyalódelegációjának tagja, $\mathrm{s}$ talán

${ }^{27}$ A ,,megfelelö emberekböl’ álló nemzeti bizottság létrehozásának szándéka valószínűleg már október 25-26. táján megfogalmazódhatott a városi pártbizottság aktivistáiban, de ezt érdemi lépés október 28-át megelőzően nem követte. ÁBTL 3. 1. 9. V-145872. Fazekas Lajos vizsgálati dossziéja. Glemba Pál tanúkihallgatási jkv., 1958. február 11.

${ }^{28}$ A megyei pártbizottság egyik jelentés szerint, amelyet Lövő Ferenc az MDP Csongrád megyei másodtitkára küldött 1956. október 29-én az MDP KV Párt- és Tömegszervezeti Osztályának, a megyei pártbizottság folyamatosan a helyén volt, és ők sikeresen vették ezt az akadályt, mivel a jelentés szerint ,, a megalakult [hódmezővásárhelyi - M. A.] nemzeti bizottságban a megyei pártbizottság képviselve van. A kezdeményezést eddig a kezükben tudták tartani”. VIDA (szerk.) 1998. 116.; A pártot a városi nemzeti bizottságban az utóbb perbe fogott, de bűncselekmény hiányában 14 hónapi vizsgálati fogság után fölmentett Török István, a megyei tanács elnökhelyettese, 1956. október 27-én Hódmezővásárhely megyei pártbizottsági javaslatra megválasztott VB-elnöke képviselte, aki - mint Németh Károly az MDP, majd az MSZMP megyei első titkára a Török elleni perben elmondott tanúvallomásában meg is erősítette - ,,a Nemzeti Bizottságon belül az akkori viszonyok között általában jól képviselte a párt irányvonalát". MNL CSML SZL XXXIII. 3. MSZMP Archívum. 1. Az MSZMP Csongrád Megyei Bizottsága iratai. Fegyelmi ügyek 1957-1983. 80. ő. e. Török István fegyelmi ügye. A Budapesti Fővárosi Tanács Népbírósági Tanácsa T. NO. VI. 0080/1958/5. sz. ítélete Török István ügyében, 1958. október 11. Nyilván ugyanezt a beszivárgási stratégiát, amely a hódmezővásárhelyi városi nemzeti bizottság október 29-ai megalakulásánál sikeres volt, szorgalmazták a járási és városi pártbizottságok munkatársainak is, és másnap, október 30-án ennek szellemében került kiadásra az MDP Csongrád Megyei Bizottsága nyilatkozata, melyben többek között az szerepel: „Az Intézö Bizottság felhívja az alakuló [járási, városi, községi, üzemi - M. A.] Intézö Bizottságokat, hogy vegyenek részt minden olyan demokratikus szervezetben - munkástanácsok, forradalmi bizottság, nemzeti bizottságok, forradalmi tanácsok-, amelyek segitik a demokratikus kibontakozást." Közli: Viharsarok XII. évf. 257. sz. 1956. október 31. 2.

${ }^{29}$ MNL CSML ML 501. a. Makó Tü. jkv. 1957. március 12. B. Papp Mihály VB-elnökhelyettes beszámolója.

${ }^{30}$ MNL CSML SZL XXV. 7. c. Csongrád Megyei Főügyészség iratai. Büntető ügyek. B 10034/1958. Ifj. Mágori Zoltán ügye. Marosi Bálint tanúkihallgatási jkv., 1957. december 20. 
a hat további javaslatba hozott kommunista egyike lehetett B. Papp Mihály országgyülési képviselő is, aki e tárgyalásról a résztvevő személyességével adott bennfentes tájékoztatást a városi tanács 1957. március 12-ei újjáalakuló ülésén. ${ }^{31}$ Mindenesetre az tény, hogy az október 28-ai „,pártközi” megállapodás része volt az is, hogy az elfogadott közös listát egy másnap megtartott népgyüléssel legitimáltatják, és ott a megállapodást megkötő politikai szereplők egyöntetűen kiállnak az elfogadott névsorban szereplők megválasztatása mellett.

Mielőtt továbbmennénk a folyamat ismertetésében, érdemes itt két közbevetést tenni. Egyrészt magyarázatot kell adnunk arra, hogy a városi MDP funkcionáriusai miért éppen Katona Sándort, az FKgP volt Csanád megyei titkárát keresték az egykori helyi kisgazda vezetők közül és nem például Szőnyi Imrét, a párt volt városi titkárát, a makói koalíciós időszak emblematikus kisgazda politikusát, aki utóbb az események fontos szereplője lett. A válasz nyilvánvalóan következett az MDP szándékaiból, illetve politikai taktikájából. Annak a célnak az elérése érdekében ugyanis, amely arról szólt, hogy a korábbi korlátlan hatalmukat valamilyen módon az új helyzetben is részben vagy egészben meg tudják őrizni, együttműködő partnerekre volt szükségük. Az országban ekkor már sokfelé tapasztalható trend világossá tette számukra, hogy az átmenet itt is kizárólag a koalíciós időszak többpárti struktúrájában képzelhető el, ezért, mivel a kezdeményezés tőlük indult, nyilván meg kívánták válogatni, az egykori koalíciós pártok szóba jöhető képviselői közül kikkel tudnának leginkább szót érteni ahhoz, hogy az átmenet (és a hatalomátmentés) számukra a legzökkenőmentesebben mehessen végbe. Az SZDP - mint baloldali párt - volt vezetői tekintetében bizonyosan nem volt vita, még akkor sem, ha ők az egykori pártnak nem a kommunistákkal kokettáló baloldali térfelén, hanem inkább a kispolgári értékeket valló jobboldali mezejében helyezkedtek el (az egyesülés előtt ezért ki is zárták őket a pártból ${ }^{32}$ ). Rajtuk kívül ugyanis a helyi SZDP-nek nem is voltak szóba jöhető képviselői. Az egykori FKgP esetében már más volt a helyzet, itt volt mérlegelési lehetőség. A régi kisgazdapárti vezetők a leszalámizás idején erőteljesen szétszóródtak és közöttük akadtak, akik az 1948-1949 után létrejött diktatórikus rendszer idején is - föladva egykori kisgazda identitásukat és elveiket - megtalálták helyüket és betagozódtak az akkor létrejött új struktúrába. Ezek közé tartozott Makón az 1945-ben még a Nemzeti Parasztpárthoz csatlakozó (e minőségében a párt Csanád vármegyei és makói vezetőségi tagja, valamint a vármegyei törvényhatóság és a makói képviselő-testület képviselője lett), majd 1947-ben a Független Kisgazdapártban pozíciót szerző (előbb még a Központi járás titkári, majd többek között Bugár János, az MKP Csanád megyei titkára ösztönzésére 1948. március 1-jével a Kisgazdapárt Csanád megyei titkári funkciót elfoglaló) Katona Sándor, ${ }^{33}$ aki már 1945-től a kommunista párttal való együttműködés készséges híve volt. Katona - bár kezdetben kétségtelenül vonakodva meghatározó szerepet vállalt a megyei és városi pártszervezet jobboldalinak és reakciósnak minősített addigi vezetőinek kiszorításában, ${ }^{34}$ és nagy valószínűséggel ennek, illetve

\footnotetext{
${ }^{31}$ MNL CSML ML 501. a. Makó Tü. jkv. 1957. március 12. B. Papp Mihály VB-elnökhelyettes beszámolója.

32 TAMASI 1974. 152.

${ }^{33}$ Lásd erről Katona é. n. 48-56.

${ }^{34}$ A Kisgazdapárt Szőnyi Imre nevével fémjelzett ,jobboldali” vezetésének kiszorításában az MDP Csanád megyei szervezetének irányító szerepét és ebben Katona Sándor feladatvállalását - egyebek között - jól mutatja az MDP Csanád Megyei Bizottsága 1948. július 20-ai ülésén a politikai pártok helyzetét taglaló napirend vitája és az elfogadott határozat. A jegyzőkönyv szerint a kommunista pártmunkások közül többen, így Bugár János megyei titkár is, Katona szemére vetették lagymatagságát és azt, hogy igyekezett kibújni a kínos személyi konfliktusok elől. Bugár arról tájékoztatta a pártbizottságot, hogy „, A Kisgazda Párt központjából Katona Sándor lehozott egy névsort kizárás céljából.
} 
megkérdőjelezhetetlen lojalitásának köszönhetően 1949-ben a Magyar Függetlenségi Népfront listájáról országgyülési képviseői mandátumot szerzett és ezt - egykori kisgazda elveit végleg sutba dobva és az MDP politikáját fönntartás nélkül fölvállalva - a következő választások során is meg tudta tartani. ${ }^{35}$ Az MDP funkcionáriusai, akik nyilvánvalóan nem szándékoztak tényleges együttműködés kialakítani a régi pártokkal, csupán egy a nemzeti bizottsági választások kimenetelét befolyásoló formális és taktikai megállapodást szerettek volna tető alá hozni velük, amely biztosíthatta volna a saját kádereik pozicionálását, olyan kisgazda vezetőt kerestek, akivel egy nyelvet beszéltek és akivel könnyen és gyorsan szót tudtak érteni. Erre a legalkalmasabb személy a fönti szempontok és célok figyelembe vételével elóélete alapján csakis Katona Sándor lehetett. Ezért lett ő a helyi „,kisgazdapárt” képviselője a tárgyaláson,

Katona kijelentette, ha mi ragaszkodunk ezek kizárásához, akkor ö szembe kerül pártjával és elszigetelik. Ezt ő nem vállalja, vagy lemond, vagy ö is elhagyja a Kisgazda Pártot. Ezzel kapcsolatban az a megállapításom, hogy fokról fokra kell akaratunkat keresztülvinni. Elöször megyeileg, majd községileg. Meg kell érteni, hogy aki nem demokrata, annak nincs helye a Kisgazda Pártban.” Kukucska János megyei propagandista arról beszélt, hogy „,A Kisgazda Párttal kapcsolatosan Katona Sándorral elővigyázatosnak kell lennünk. Mi mozgassuk a Kisgazda Párt megyebizottságát, ne egyedül Katona végezze ezt a munkát. Amikor Szőnyi [Imre] ügyét tárgyalta a Nemzeti Bizottság, Katona nem jött el - mint mondotta - azért, mert tudta, hogy Szőnyi ügyét tárgyaljuk és neki az a véleménye, végezzük el mi ezt a tisztogatást, de öt ne kompromittáljuk. Nekünk meg kell értetni a kisgazdákkal, hogy mi támogatjuk őket, de a tisztogatást nekik maguknak kell elvégezni." Ehhez csatlakozott a kommunista megyei napilap szerkesztője, Koncsek László is: „,Ami Katonát illeti, neki gátlásai vannak. Fél a kulákoktól. Nincs mögötte tömeg, mert még mindig van ott egy tömeg, amely uralja a pártot: a Szönyi-féle klikk. Vannak ott Szönyinek emberei, akik továbbviszik a hatalmi politikát. Ha mi a tisztogatást úgy tudjuk végrehajtani, hogy legelöször ezt a klikket robbantsák fel, akkor ez nem fogja többé Katonát gátolni, hogy megyebizottságuk müködését is sokkal jobban befolyásolni tudjuk.” A pártbizottság a hozzászólások szellemében hozott határozatot a Kisgazdapárttal kapcsolatos további politikai lépésekről. A határozatból idézve: „Kukucska elvtárs hozzászólása alapján megállapítja a megyebizottság, hogy a Kisgazda Párt titkára, Katona teljesen ránk akarja hárítani azt a munkát, amit nekik kell elvégezni. Ha nem ök maguk hajtják végre belülröl a tisztogatást, akkor úgy néz ki a dolog, hogy kívülröl rájuk kényszeritjük. Akkor nem tisztogatás megy végbe, hanem eröszakos mártírság." Majd másutt: „, A Kisgazda Párttal szemben Szücs [Ferenc], Katona és Kovács Bélával visszük tovább az akciót. Katonával szemben egy kicsit szigorúbbak leszünk és nem teszünk olyan engedményeket, mint eddig, mert már nincs idö. Nem egyedül Katonára támaszkodva, hanem a Kisgazda Párt megyebizottságára támaszkodva kell részleteiben meginditani az akciót." MNL CSML SZL XXXIII. 3. MSZMP Archívum. 40. Az MDP Csanád Megyei Bizottsága iratai. 1. 2. Megyebizottsági ülések jegyzőkönyvei. Az 1948. júl. 20-i ülés jkv. Szőnyiék teljes kiszorítása a Kisgazdapártból hamarosan sikerre vezetett, nincs adat arra, hogy Katonának további aggályai merültek volna föl a leszámolást illetően, amit végre is hajtott, bár határozatlansága miatt még augusztusban is kapott az MDP megyei bizottsági ülésén kritikát, ahol Kukucska János megjegyezte vele kapcsolatban: „, Katona Sándor lagymatag. A kizárásokat úgy hajtja végre, hogy a kizárt tagoknak megmondja, »ha szeretitek a pártot, akkor végrehajtjátok a központ utasítását«." A kizárásokra egyébként azzal az indokkal került sor, hogy ,,kulák nem lehet a Kisgazda pártnak tagja”. MNL CSML SZL XXXIII. 3. MSZMP Archívum. 40. Az MDP Csanád Megyei Bizottsága iratai. 1. 2. Megyebizottsági ülések jegyzőkönyvei. Az 1948. aug. 24-i ülés jkv. Katona egyébként a Történelmi sorsforduló címü kéziratos visszaemlékezésében nem tartotta fontosnak megemlíteni a Kisgazdapárt megyei és makói szervezete „megtisztitásában” játszott szerepét.

${ }^{35}$ Lojalitásának elmélyítését minden bizonnyal segítette az a visszaemlékezésében említett eset, miszerint Bugár János Csanád megyei párttitkár az 1949-es mandátumszerzését megelőzően egy dokumentumot kívánt vele aláírattatni, melyben arról nyilatkozik, hogy lemond országgyűlési képviselői mandátumáról. A dokumentum természetesen az MDP megyei titkárához került volna , letétbe”. A politikai zsarolás, illetve zsarolhatóság eme dokumentuma szükség esetén a kommunista párt részéről bármikor fölhasználható lett volna ellene, s persze tudjuk, hogy rendelkezésre álltak más, ennél direktebb módszerek is. „, Akkor döbbentem rá - irta Katona -, hogy a képviselöi mandátum az MDP Pártközpont alkalmazottainak kezében van, jó- vagy rosszindulatuktól függ, hogy a képviselöi megbizatás meddig tart. A Kisgazdapárt felé megnyilvánult bizalmatlanság óvatosságra figyelmeztetett a politikai munkában.” KATONA é. n. 75-76. Valóban, politikai munkája során - kerülve a konfliktusokat - belesimult a pártállami rendszerbe. 
aki - mint a végeredmény is mutatja - nyilvánvalóan nem gördített akadályt az elé, hogy a „közös listára" kommunista jelöltek is fölkerüljenek. ${ }^{36}$

Hasonló logika érvényesülhetett - és ez a másik közbevetésünk - a tárgyalásra meghívott fiatalok képviselőinek kiválasztásánál is. Arról, hogy a megbeszélés résztvevői között jelzett ifjúságot képviselő meghívottak személy szerint kik voltak, semmilyen adatunk nincs, pedig ennek az események későbbi alakulása - elsősorban a makói Forradalmi Ifjúsági Szövetség (FISZ) október 31-ei megszerveződése - szempontjából kiemelt jelentősége volt. Tekintettel ugyanis arra, hogy a ténylegesen létrejövő városi nemzeti bizottságban azok közül a fiatalok közül, akik a forradalom első napjaiban, illetve majd utóbb a FISZ-ben érdemi szerepet vállaltak, egy későbbi állambiztonsági nyilvántartás szerint mindössze Békési János tanuló, a FISZ majdani fegyveres tagja kapott helyet ${ }^{37}$ (azonban az ő neve sem szerepelt a bizottság létrehozásakor elfogadott listán, ${ }^{38}$ így föltételezhetően ő is csak később kerülhetett be informálisan a nemzeti bizottságba, hiszen formális választást október 30-át követően már nem tartottak), gyanítható, hogy az MDP funkcionáriusai által kezdeményezett népfrontos megbeszélésen csupán az állampárt addigi ifjúsági szatellit-szervezetének, a DISZ-nek az ismeretlen képviselői voltak jelen. Az ő feladatuk is mindössze annak demonstrálása volt, hogy az előkészítés milyen széles társadalmi bázison történik, ám érdemi beleszólásuk az előkészítő munkába nagy valószínűséggel nem volt és nem is lehetett.

Mindenesetre az október 28. délutáni tárgyalás az MDP szándékai és reményei ellenére nem ment könnyen, még akkor sem, ha a végén a maguk számára összességében előnyös kompromisszumot sikerült kötniük. A szociáldemokraták ugyanis vonakodtak, illetve föltételeket szabtak az egyeztetés során. Érdemes erről idézni az egyetlen, az események lezajlódása tekintetében valamennyire autentikusnak tekinthető, bár nyilvánvalóan nem elfogulatlan forrást, B. Papp Mihály VB-elnökhelyettesnek a városi tanács 1957. március 12-ei újjáalakuló ülésén elhangzott beszámolója ide vonatkozó részét: „,Azért, hogy a fegyelmet, a közbiztonságot mégis biztositani lehetett, hogy ne gyilkoljanak itt is embereket, ne rabolják ki az üzleteket, a szétesöben lévö államhatalmi szerv helyébe a párt megbizásából több elvtárs közremüködésével [1956. október 28. - M. A.] délután 2 órára a Hagymaházba összehívták a volt koalíciós pártok

${ }^{36}$ Érdekes, hogy Katona Sándor, aki Történelmi sorsforduló című visszaemlékezésében szinte napról-napra leírta, mi történt vele a forradalom idején, erről a tárgyalásról nem tett említést. Meglehet, azért hallgatta el, mert annak kimenetele nyilvánvalóan kudarc volt számára. Éppen ezért nem írt a nemzeti bizottság létrejöttéről sem. Azt viszont fontosnak tartotta rögzíteni, hogy október 27-én meg nem nevezett makói értelmiségiek megkeresték őt, hogy vállalja el a nemzeti bizottság elnökségét. Ezt a fölkérést azonban állítása szerint visszautasította. Arra vonatkozóan, hogy ez a fölkérés valóban megtörtént-e, s e mögött volt-e bármiféle társadalmi akarat, hiteles információval nem rendelkezünk, egyéb forrás nem erősíti meg. Mindenesetre Katona írása és gondolatmenete inkább arról árulkodik, hogy egy lehetséges fölvetés utólagos megszínezéséről, egyfajta konfabulációról lehet itt szó. A visszaemlékezésben az alábbiak olvashatók: „,̈sszetalálkoztam a József Attila MTSZ egyik tagjával, aki évekig, 1954-1955-ben brigádvezetöm volt. Bementünk a nagy cukrászdába egy kávét inni. Alighogy leülünk, egy megyei, egy járási müvelödésügyi osztályon dolgozó pedagógus és egy iskolaigazgató jött hozzám, hogy a makói értelmiség engem szeretne felkérni a városi nemzeti bizottság elnökének. Nem vállaltam azzal az indoklással, hogy engem Székkutas községbe köt a hivatali esküm [Katona 1956. február 16. óta Székkutas község VB-elnöke volt - M. A.], és miután a vonatok nem közlekednek, október 29-én én oda gyalog is visszamegyek. Úgy néztek rám, mint aki bezsongott, és amikor elmentek, még a velem szemben ülö TSZ brigádvezetö is azt mondta, hogy nem helyes Sándor bátyám, hogy a felkérést nem fogadtad el. A bizalom nagy erkölcsi erö és te sokat tudnál tenni a bizalom támogatásával. Nem vállalom, mert én nem ezt tartom fontos kérdésnek, a Szovjetunió nem fogja eltürni, hogy akasszák, agyonverjék a kommunistákat, meggyalázzák a szovjet hösi emlékmüveket. A teljes katonai megszállás következik a Varsói Szerződés alapján." KATONA é. n. 118.

${ }^{37}$ ÁBTL 3. 1. 9. V-150355/2. Összefoglaló a forradalmi bizottságokról. 31.

${ }^{38}$ То́тн 1996. 5-7. Makó Város Nemzeti Bizottságának névsora. 
vezetőit. Megjelent az MDP, Nemzeti Paraszt Párt, Kisgazda Párt, Szociáldemokrata Párt, Zombori [Lajos], Kiss [Ernő] és Lukács [Pál] és az ifjúság két képviselője. Az MDP részéröl Kalász [József] elvtárs előadta, hogy miért jöttünk össze a megbeszélésre, de a megbeszélésböl diktátum lett, mert a Szociáldemokrata Párt régi jó szokásához híven feltételekhez kötötte a segitségadást. Zombori elövette zsebéböl a diákság követeléseinek 15 pontját, hogy csak ennek az elfogadása alapján hajlandók tovább tárgyalni. Jobb hiján elfogadtuk mindannyian. Ez után Kiss Ernö kijelentette, hogy a további tárgyalásunk alapja az: elöször a kormányt nem ismeri el, pedig akkor már Nagy Imre kormány volt, pár napig nem veszik át a hatalmat, hagy bünhödjenek elöbb a bünösök. Másodszor, a karhatalom és a posta rendelkezésükre álljon. Mindez alapos elökészitésre enged következtetni és valószínüvé tette, hogy régebb idö óta készülnek, vagy még elö is készitették a bekövetkezett forrongást. A későbbiek folyamán jobb belátásra lehetett birni és kijelöltük a bizottság 11 tagját és a nagy bizottság 30 tagját." "39

B. Papp Mihálynak a tárgyalásról adott összefoglalójáról természetesen le kell hántani a forradalmat tudatosan előkészítő és a tárgyalásra már kész tervekkel érkező szociáldemokratákra vonatkozó, egyébként teljességgel megalapozatlan kliséket. Ezek nyilván a később bekövetkező fejlemények (a másnapi választás sikertelensége) miatti felelősség áthárítására vonatkozó utólagos érvek voltak B. Papp részéről. Érdekesebb, ha ettől lecsupaszítjuk a tárgyalást, és észrevesszük az egyeztetés két, előbb egymással szemben álló és vonakodó, majd utóbb alkut kötő oldalát. Egyik oldalon az elbizonytalanodó kommunisták ültek, akik bevallottan ,,segítségadásért" (és be nem vallottan kényszerből) fordultak hatalmuk átmentése érdekében a szociáldemokratákhoz, a másik oldalon pedig a szintén bizonytalan szociáldemokraták ültek, akik ugyan ismerték a ,fiatalok”, azaz a forradalom követeléseit és annak pártján voltak, de akik aztán igen nehezen szánták rá magukat a váratlan döntési szituációban való egyértelmű állásfoglalásra. Az általuk fölvetett szempontok (B. Papp szerint a diktátum) akár hirtelenjében végiggondolt racionális biztosítékok, akár időt húzó, s a helyzet alaposabb átgondolását lehetővé tevő fölvetések is lehettek, utólag ez nem eldönthető. De kizárt, hogy a szociáldemokraták részéről tudatos és átgondolt tárgyalási technikáról lett volna szó, sokkal inkább az óvatosságuk és a bizonytalanságuk megnyilvánulásáról. A megegyezés alól azonban nem tudtak kitérni, talán nem is akartak, ez sem tudható biztosan. Mindenesetre a felelősséget a makói események alakulásáért nyilvánvalóan nem kívánták magukra húzni, s akár hízeleghetett nekik, hogy vezető pozícióhoz juthatnak az új helyi néphatalmi szervben, ezért aztán ők is elfogadták a pillanatnyi helyzetben mindkét fél számára legjobbnak tünő kompromisszumot: a közös népfrontos jelöltlistát, melyben nyilván valamilyen arányban megjelentek az egyezségben részt vevő politikai szervezetek képviselői és amelynek élén nagy valószínűséggel a szociáldemokraták jelöltje (talán éppen a későbbi nemzeti bizottsági elnök, Zombori Lajos) állhatott.

A nemzeti bizottság létrehozását célzó előkészületeket látva és annak elősegítése érdekében, hogy az MDP által koordinált népfrontos városirányítói lista zavartalanul elfogadható legyen - és nyilvánvalóan a megyei, esetleg a városi pártbizottság utasítására -, október 29-én reggel Földházi Imre VB-elnök és helyettese benyújtotta lemondását a megyei tanács VB-elnökéhez írott levelében. ${ }^{40}$ Ezzel elhárult a formális akadálya annak, hogy Makón békés hatalomátvételre

${ }^{39}$ MNL CSML ML 501. a. Makó Tü. jkv. 1957. március 12. B. Papp Mihály VB-elnökhelyettes beszámolója.

${ }^{40}$ Az eredeti lemondó nyilatkozatot lásd: MNL CSML ML 503. 4. c. Makó Város Tanácsa VB Titkársága iratai. Személyzeti csoport iratai. 14-37/1956. Földházi egyébként erről a lépéséről az eseményekről - saját olvasatában komplex áttekintést nyújtó 1957. március 9-ei, a Csongrád Megyei Tanács VB-elnökének írt összefoglaló jelentésében szemérmes hallgatásba burkolódzott. MNL CSML ML 515. a. 1763/1957. Földházi Imre VB-elnök jelentése. A jelentést teljes terjedelemben közli: Tóтн 1996. 31-45. 
kerülhessen sor. Az új népképviseleti szerv megválasztása azonban az MDP párfunkcionáriusok nem kis csalódására két ütemben történt, mivel a népgyülésen megjelenő makóiak nem teljesen úgy és nem azokkal a jelöltekkel képzelték el jövőjüket, akik az előző napi megállapodásban rögzített pártközi listán szerepeltek. Emiatt az első szakasznak az október 29-én délelőtt a Kossuthszobor előtt megrendezett nagygyülést tekinthetjük, ahol természetesen az SZDP, az FKgP és az MDP képviselői is jelen voltak.

A több ezer főt utcára szólító 29-ei népgyűlés sokak hozzászólását követően először egy 22 pontból álló követelést fogadott el, melyben - többek között - a szabadságjogok helyreállítása, a szovjet csapatok kivonása, a Varsói Szerződésből való kilépés, az adóterhek csökkentése és a nemzetőrség felállítása szerepelt, ${ }^{41}$ majd az előkészítő megállapodásban foglaltaknak megfelelően ismertették azok nevét is, akiket az előző napi pártközi egyeztetésen a volt koalíciós pártok a nemzeti bizottságba beválasztani javasoltak. Mivel az esemény lefolyásáról két - bár utólagos - forrás is rendelkezésre áll, érdemes mindkettőt szó szerint idézni, mivel jól kiegészítik egymást. Az egyik forrás Marosi Bálint kultúrházigazgatótól származik, akinek neve szerepelt az előzetes pártközi egyezség alapján beterjesztett jelöltlistán és aki utóbb a tüntetésen személye ellen markáns hangon fölszólaló ifj. Mágori Zoltán elleni büntetőeljárás során tett tanúvallomásában ekként idézte föl - saját szemszögéből - a történteket: ,,1956. október 29-én egy tömeggyülés lett összehivva a Kossuth-szoborhoz. Ez alkalommal a tömeghez kimentem én is a fentebb említett [városi - M. A.] pártbizottság által javasolt elvtársakkal. A tömegnek az volt a követelése, hogy minden egyes tag, akit meg akartak választani, személyesen álljon ki. Mikor rám került a sor, akkor hallottam, hogy a tömegben tölem nem messze álló ifj. Mágori Zoltán az alábbi kijelentéseket tette rám: »Le Marosival, nem kell nekünk Marosi, mert ávós volt, most is abban a ruhában van. $\aleph^{42}$ Valóban katonanadrág volt rajtam. Mikor a tömeg a fentieket hallotta, nem választottak meg nem csak engemet, hanem a pártbizottság által javasolt egyetlen elvtársat sem. Tekintettel arra, hogy a volt járási MDP bizottság a Kossuth-szoborral szemben van, igy az MDP Bizottság akkori vezetöi kijöttek az erkélyre, hogy a gyülést meghallgassák. Ez alkalommal Mágori Zoltán hangosan kiabálni kezdte, »Nem féltek, hogy lehúzunk benneteket onnan?«. Nevezett kijelentései és magatartása olyan volt, hogy a tömeget lázítsa és igyekezett ellenünk kommonisták [sic!] ellen a tömeget hangolni. Hogy verekedésre nem került sor, az csak annak volt tudható, hogy az akkor kivonult tsz tagok megakadályozták ebben az ellenforradalmárokat." ${ }_{43}$

Arról, hogy valóban verekedésbe hajló volt-e a hangulat az október 29-ei Kossuth-szobor előtti nemzetibizottságválasztó nagygyűlésen és ezt csak a pártbizottság által kivezényelt tsz-tagok demonstratív föllépése akadályozta meg, nem rendelkezünk autentikus információval, de éppen a másik megmaradó forrásunk, Földházi Imre VB-elnök 1957. márciusi jelentése valószínűsíti, hogy a feszült és indulatokkal teli légkör ellenére ilyesmire nem került sor, mert ha lett volna erre utaló jel, azt egészen bizonyos, hogy belevetette volna a valósághoz képest egyébként is sok mindent kiszínező tanácsi jelentésébe. ${ }^{44}$ Marosi állításával szemben Földházi beszámolójában az esemény lefolyásával kapcsolatban - szó szerint idézve - a következők olvashatók: „,29-én újabb gyülést tartottak a Kossuth szobornál, amelyen már teljesen népidemokrácia

\footnotetext{
${ }^{41}$ TóTH 1996. 4-5. Makó város dolgozó népe és ifjúsága 22 pontos követelése.

${ }^{42}$ Arról, hogy Marosi Bálint korábban az ÁVH állományában szolgált volna, nem rendelkezünk megerősítő adattal.

${ }^{43}$ MNL CSML SZL XXV. 7. c. B. 10034/1958. Ifj. Mágori Zoltán ügye. Marosi Bálint tanúkihallgatási jkv., 1957. december 20.

${ }^{44}$ Nem tettek erre utaló észrevételt az eljárás során meghallgatott további tanúk, így a városi tanács munkatársai, Karsai András VB-titkár és Hegyi György pénzügyiosztály-vezető sem, akik szintén jelen voltak az eseményen.
} 
ellenes, szovjetellenes hangulat lett úrrá. [...] Ezen a gyülésen bejelentették a nemzeti bizottság megalakitását. Itt meg kell emliteni, hogy a bizottság megalakitására folyó tárgyalásokban az elözö napon a városi pártbizottság is részt vett. Így a bizottságba kommunisták is voltak jelölve. Amikor azonban ezek neveit is felolvasták, a tömeg ezeket kifütyülte, kikiabálta. Ekkor bejelentették, hogy a következö napon a Járási Tanács épülete elött újabb népgyülés lesz, ahol az egész nép fogja megválasztani a városi nemzeti bizottságot." ${ }_{45}$

Miután tehát a listán szereplő és az MDP városi pártbizottsága által javasolt kommunista jelölteket a tömeg indulatosan kifütyülte, a népgyülés alkalmatlanná vált arra, hogy a bizottságot megválassza. Azt a kockázatot ugyanis, hogy a tömeg a helyszínen közvetlenül és ellenőrizetlenül válasszon meg nemzeti bizottsági tagokat, a gyülést levezénylők közül senki sem merte magára vállalni. A döntést ezért másnapra halasztották, miután fölhívták a megjelentek figyelmét, hogy „, minden üzem, intézmény, hivatal vagy szervezet jelöltjeit juttassa el az elökészítö bizottsághoz” ${ }^{46}$ E másnapi gyülés lett a hatalomátvétel második üteme.

Hogy elkerüljék az újbóli kudarcot, október 29-én délután egy jelölőbizottság készítette elő másnapra az új jelöltlistát. Itt már az SZDP és az FKgP politikusai voltak a kezdeményezők, a délelőtti sikertelenségből okulva az MDP képviselőinek nem adtak teret, ugyanakkor továbbra is ügyeltek mind az előkészítés, mind pedig a választás népfrontos jellegének megőrzésére, de most már a kommunisták nélkül. A jelölőbizottságban az SZDP-t Zombori Lajos, Kiss Ernő és Lukács Pál, az FKgP-t dr. Diósszilágyi Sámuel orvos és dr. Bogdán József fogorvos, míg a Nemzeti Parasztpártot (NPP) Erdei Ferenc földműves képviselte, de rajtuk kívül még többen (így például rövid ideig Fazekas Lajos rendőrkapitány) is jelen voltak a jelöltállítás során. ${ }^{47}$ Az MDP még itt és ekkor is kísérletet tett arra, hogy embereit jelöltté nyilváníttassa, e szándékot azonban a jelölőbizottság - szemben az előző napi egyeztetésben foglaltakkal - már egyértelmüen elutasította. ${ }^{48} \mathrm{~A}$ városi pártbizottság egyik képviselője utólag meg is állapította: , $A z F N B$-ből [azaz a Forradalmi Nemzeti Bizottságból - M. A.] kiszoritották a beküldött párttagokat." ${ }_{49}$ Hasonlóképpen fogalmazott Glemba Pál, a városi pártbizottság titkára is, aki másfél évvel később, a büntetőeljárás alá vont Fazekas Lajos rendőrkapitány ellen folytatott nyomozás során tett tanúvallomásában azt mondta: „Az általunk létrehozott »Nemzeti Bizottságot « tömeggyülésen teljesen megváltoztatták, az általunk bedelegált párttagokat vagy mérsékeltebb embereket kiszórták, s a »Nemzeti bizottság « döntö többsége osztályidegen, illetve ellenséges elemekböl tevödött össze." ${ }_{50}$

Arról, hogy az MDP helyi pártvezetői rosszul élték meg a kudarcot, egy másik dokumentum is tanúskodik. Lövő Ferenc az MDP Csongrád megyei másodtitkára 1956. október 29-én természetszerűleg a helyi pártszervektől beérkezett információk alapján összefoglaló jelentést küldött az MDP KV Párt- és Tömegszervezeti Osztályának a párt aktuális megyei helyzetéről. A jelentésben - amely többek között tájékoztatott arról, hogy a Csongrád megyei pártbizottság ura a helyzetnek, a frissen megalakult hódmezővásárhelyi nemzeti bizottságban képviseletet tudtak maguknak biztosítani és a kezdeményezést is kezükben tudták tartani - többek között az alábbiak is olvashatók: „, járási pártbizottságok szintén müködnek, arra törekszenek, hogy

\footnotetext{
${ }^{45}$ MNL CSML ML 515. a. 1763/1957. Földházi Imre VB-elnök jelentése.; TóTH 1996. 33.; lásd még BÁLINT 2006.47.

${ }^{46}$ MNL CSML ML 515. a. 1763/1957. Földházi Imre VB-elnök jelentése.; Tóтн 1996. 33.

${ }^{47}$ MNL CSML ML 515. a. 1763/1957. Földházi Imre VB-elnök jelentése.; TóTH 1996. 33.; ÁBTL 3. 1. 9. V-145872. Fazekas Lajos vizsgálati dossziéja. Fazekas Lajos kihallgatási jkv., 1958. január 24.

${ }^{48}$ BÁlint 2006. 50.

${ }^{49}$ Idézi BÁlinT 1996. 132.

${ }^{50}$ ÁBTL 3. 1. 9. V-145872. Fazekas Lajos vizsgálati dossziéja. Glemba Pál tanúkihallgatási jkv., 1958. febr. 11.
} 
a kezdeményezés az ő részükröl megmaradjon. A járási pártbizottságok részéröl a makói járásnak a legnehezebb a helyzete, tömegnyomással ki akarják öket szoritani a megalakult nemzeti bizottságból." ${ }^{11}$ Tekintettel arra, hogy a makói járási nemzeti bizottság megalakítására - mint erről később szó esik - csak november 3-án került sor, és a létrehozás mögött a járási tanács apparátusának komoly szervezőmunkája állt, egyértelmű, hogy itt nem a járási, hanem a városi nemzeti bizottság megalakulása körüli, az MDP számára kedvezőtlen október 29-ei fejleménnyel kapcsolatos információk fölterjesztéséről volt szó és pontosan jelzi, ami a pártfunkcionáriusoknak nyilvánvalóan nem tetszett: azt, hogy a makóiak nem dőltek be az MDP másutt - így a megyeszékhely Hódmezővásárhelyen - többé-kevésbé sikeres hatalomátmentési stratégiájának, és a tömeg nem akarta az új városi hatalmi szervben látni a kommunista párt embereit.

Október 30-án délután mintegy háromezer ember jelent meg a járási tanács székháza előtt, így a nemzeti bizottság megválasztására valóban egyfajta népgyülés keretében került sor. A személyi javaslatokat az erkélyről Szőnyi Imre az FKgP egykori politikusa - más adat szerint Vajda Imre, a Szociáldemokrata Ifjúsági Mozgalom (SZIM) volt Csanád vármegyei titkára ${ }^{52}$ - ismertette, de a támogató fölszólalók között szerepelt a szociáldemokrata Kiss Ernő is. Noha az előterjesztett névsor , kompromittált”, azaz ismert kommunista személyek nevét már nem tartalmazta, mégis volt néhány eset, amikor a tömegből többen zúgolódtak. ${ }^{53}$ Ennek ellenére az eredetileg beterjesztett 70 fős listánál nagy valószínűséggel már ekkortól nagyobb létszámú testület tagjait a jelenlévők egy kivétellel (Fazekas Lajos rendőrkapitány állítása szerint a szociáldemokrata Vajda Imrét nem választották meg) elfogadták és megerősítették. ${ }^{54}$ Utóbb Földházi Imre VB-elnöknek is el kellett ismernie, hogy az itt megválasztott nemzeti bizottság lefedte a város

${ }^{51}$ VIDA 1998. 116.

${ }^{52}$ ÁBTL 3. 1. 9. V-145872. Fazekas Lajos vizsgálati dossziéja. Fazekas Lajos kihallgatási jkv., 1958. január 24. Fazekas Lajos vallomásában nevet nem említett, csupán annyit közölt, hogy „, a SZIM megyei titkára ismertette a névsort, hogy kik legyenek a $N$ [emzeti] $B$ [izottság] tagjai”. Tekintettel arra, hogy a nemzeti bizottság eredetileg beterjesztett 70 fős listájában (annak is az igen előkelő 4. helyén) csupán Vajda Imre nevét találtuk meg (lásd TóTH 1996. 5. Makó Város Nemzeti Bizottságának névsora.), aki 1946-ban valóban a SZIM Csanád vármegyei titkára volt (Lásd pl. Makói Népújság II. évf. 65. sz. 1946. március 22. 3.), szinte biztosra vehető, hogy Fazekas rá utalhatott vallomásában.

${ }^{53}$ A családi emlékezet szerint ilyen atrocitás történt Szemere (Schwarz) Manó, a makói zsidóság közismert alakja megválasztásakor. Unokaöccse, Lantos Péter önéletrajzi könyvében ezt a következőképpen örökítette meg: „A forradalmi felbuzdulásban nemzeti bizottságok szervezödtek, hogy a nép lehetö legszélesebb rétegeit képviseljék. Egy gyülés alkalmával, amelyen a helyi bizottság tagjait akarták megválasztani, Manó bácsit mint volt szocdem vezetöt is jelölték, de valaki bekiabált: - Nem kellenek a zsidók! Nem akarjuk a kommunista zsidókat!" (LANTos 2009. 197.) Nincs okunk kételkedni az eset megtörténtében, ugyanakkor nincs autentikus forrás, amely ezt megerősítené vagy cáfolná. Ami tény, hogy Szemere Manó neve nem szerepelt azon a hetven fős listán, melyet jóváhagyásra az előző napi pártközi megállapodás nyomán a népgyülés elé terjesztettek (lásd TóTH 1996. 5-7. Makó Város Nemzeti Bizottságának névsora.), de ez önmagában nem perdöntő, hiszen valószínűsíthető, hogy a lista menet közben változott, és voltak olyanok, akiket a beterjesztett neveken felül választottak meg. Ezek közé tartozhatott Szemere Manó is, amit alátámaszt, hogy mint bizottsági tag vett részt és tett indítványokat a városi nemzeti bizottság másnapi, október 31-ei ülésén. (Tо́тн 1996. 12-15. Jegyzőkönyv a makói nemzeti bizottság október 31-ei üléséről.) Arról viszont semmilyen adatunk nincs, hogy megválasztására az egykori párttagsága nyomán a szociáldemokrata pártot képviselő Kiss Ernő vagy Zombori Lajos kezdeményezésére került volna sor, a forradalom idejéből megmaradt, a szociáldemokratákra vonatkozó adatok között legalább is a neve nem szerepel. Mindenesetre ki sem zárható, sőt, inkább valószínűsíthető, hogy jelölésére és megválasztására valóban ezen a módon és emiatt került sor. Szemere Manó életútjáról és közéleti szerepvállalásáról lásd részletesen URBANCSOK 2018. A Lantos Péter által megörökített antiszemita közbekiabálással kapcsolatban mindazonáltal meg kell jegyeznünk, hogy a forradalom napjaiban történtek kutatása során semmiféle forrásokkal alátámasztható zsidóellenes kilengéssel nem találkoztunk, és a helyi emlékezet sem őrizte meg ilyen jelenség nyomát.

${ }_{54}^{5}$ ÁBTL 3. 1. 9. V-145872. Fazekas Lajos vizsgálati dossziéja. Fazekas Lajos kihallgatási jkv., 1958. január 24. 
társadalmának minden lényeges területét. Miként az eseményeket összegző jelentésében fogalmazta: „A bizottság összetétele igen különbözö volt, meg kell hagyni, minden foglalkozású rétegböl kerültek bele." ${ }_{55}$

A választás menetéről semmiféle korabeli dokumentummal nem rendelkezünk (az eseményen jelen lévő Fazekas Lajos rendőrkapitány a büntetőeljárása során tett vallomásában annyit rögzített, hogy „, a gyülés a választással együtt mindössze egy órahosszát tartott, ahogy vége lett, a tömeg széjjeloszlott”s6), ezért nem tudjuk, hogy az akkor létrejött nemzeti bizottságnak a megválasztásakor és az azt követő napokban pontosan hány tagja volt. Mivel az általunk jelzett és a népgyülés elé terjesztett 70 fós előzetes nemzeti bizottsági lista megmaradt, ${ }^{57}$ ez az egyetlen biztos kiindulópont, ami azonban nem zárja ki, hogy már az alakuláskor újabb és más tagokat is megválasztottak. Mindemellett tudjuk azt is, hogy a következő napokban is bekövetkeztek változások a nemzeti bizottság összetételében, erre Bálint László is fölhívja a figyelmet. ${ }^{58}$ Voltak, akik lemondtak és jöttek új szereplők, akiket viszont nem választottak meg, hiszen újabb nemzetibizottságválasztó népgyülést október 30. után már nem tartottak. Ezekkel az időközben bekövetkező változásokkal függhet össze, hogy az ismert és eredetileg beterjesztett 70 fős létszámhoz képest jóval magasabb számot, egy 87 fős adatot közöl az a „,Monográfia”, amelyet 1959-ben a BM Csongrád Megyei Rendőrfőkapitányság Politikai Nyomozó Osztályának nyomozói az 1956-ban tevékeny szerepet betöltő személyekről állítottak össze a korábbi vizsgálati anyagok alapján (Monográfia az 1956. október 23-án kirobbant ellenforradalom következtében Csongrád megyében létrejött „,forradalmi nemzeti bizottságok” és a ,,munkástanácsok” tagjairól, valamint azok tevékenységéről). Ez a „,Monográfia” azonban nem teljes körü, mivel összesen 16 személyt nevesít és ismertet, a többiekről csupán annyit közöl, hogy ,, a fent felsorolt személyeken kívül még 71 tagja volt a Makó városi nemzeti bizottságnak" ${ }^{59}$ Emiatt e forrás alapján a szükséges egybevetéseket a hetven fős eredeti listával nem tudjuk elvégezni.

A fönti dokumentum mellett létezik egy a Szegedi Rendőrfőkapitányság politikai nyomozói által szintén 1959-ben készített másik lista is (Összefoglaló a forradalmi bizottságokról), ez összesen 90 személyt említ a makói nemzeti bizottság tagjai között, közülük azonban csak 21 személyt nevez meg, akiknek röviden ismerteti előéletüket is. ${ }^{60}$ Hasonlóan 90 tagú nemzeti bizottságról beszélt később az egyik volt bizottsági tag, Csuthy Gizella is. ${ }^{61}$ A képet tovább színezi, hogy egy 1957 áprilisi tanácsi jelentés még ennél is nagyobb létszámú, több mint 90 fős nemzeti bizottságot említ, s közli azt is, hogy a „,tagjainak száma állandóan nött”. Konkrét adatokat

\footnotetext{
${ }^{55}$ MNL CSML ML 515. a. 1763/1957. Földházi Imre VB-elnök jelentése.; Tóтн 1996. 34.

${ }^{56}$ ÁBTL 3. 1. 9. V-145872. Fazekas Lajos vizsgálati dossziéja. Fazekas Lajos kihallgatási jkv., 1958. január 24. Fazekas ugyanebben a vallomásában az esemény lefolyásáról még a következőket közölte: „,A délelötti órákban a Járási Tanács elötti téren volt megtartva. A szónokok az erkélyéröl beszéltek. Szőnyi [Imre] (FKP) bejelentette, hogy az elökészitö bizottság listát készitett, hogy kiket javasolnak a $N$ [emzeti] $B$ [izottság]ba. Beszéde többi részében igen szélsőséges volt, több kirohanást intézett a tsz-ek ellen. Emiatt beszédét meg is kellett szakitani, Kiss Ernö (SZDP) fejezte be. Ezt követöen a SZIM megyei titkára ismertette a névsort, hogy kik legyenek a $N$ [emzeti] $B$ [izottság] tagjai. A jelenlévö többezres tömeg ezt elfogadta, illetve egyes esetekben észrevételt tett, de ez nem lett figyelembe véve. Mindössze egy esetben, amikor is a volt SZIM titkárt [tehát Vajda Imrét - M. A.] nem fogadták el." ÁBTL 3. 1. 9. V-145872. Fazekas Lajos vizsgálati dossziéja. Fazekas Lajos kihallgatási jkv., 1958. január 24.

${ }^{57}$ TóтH 1996. 5-7. Makó Város Nemzeti Bizottságának névsora.; lásd még BÁLINT 2006. 55-57.

${ }^{58}$ BÁLINT 2006. 57.

${ }^{59}$ FEJÉr 2009. 127-129.

${ }^{60}$ ÁBTL 3. 1. 9. V-150355/2. Összefoglaló a forradalmi bizottságokról. 28-32.

${ }^{61}$ MNL CSML ML 515. a. 4775/1957. Csuthy Gizella fegyelmi meghallgatási jkv., 1957. július 18.
} 
viszont ez a dokumentum sem tartalmaz. ${ }^{62}$ A Csongrádmegyei Hírlap címü napilap a 1956. november 28-ai számában pedig , közel százas létszámú" testületről írt, nevek itt sem olvashatók. ${ }^{63}$ A fentiek ismeretében - bár konkrét adatok hiányában - föltételezhető tehát, hogy az október 30-ai nemzetibizottságválasztó nagygyülésen a beterjesztett 70 főhöz képest valóban több személyt választottak meg, és esetleg voltak vagy lehettek olyanok is, akik választás nélkül, valamilyen szervezet delegáltjaként csatlakoztak utóbb tagként a nemzeti bizottsághoz. Ezt támasztja alá például a november 1-jén megalakított Magyar Parasztszövetség makói szervezetének november 3-án kelt levele, amelyben a 12 tagú intéző bizottság nevében Báló János arról tájékoztatta a nemzeti bizottság vezetőit, hogy ,, a Nemzeti Bizottságba az érdekképviseleti szerv megbizottjaként dr. Tokai [helyesen Tokaji - M. A.] Ferencet és Bíró Györgyöt küldjük be" ${ }^{64}$

A fönti adatok nyomán valószínüsíthető, hogy a makói nemzeti bizottságnak 90 és 100 fö között lehetett a száma, amely egyébként hozzávetőlegesen megfelelt a korábbi városi tanács 100 föben meghatározott létszámának.

A ,,nyilt ülés” után a nemzeti bizottság a járási tanács épületében egy a korábbi 13 fős végrehajtó bizottság funkcióit átvevő és operatív feladatokat ellátó, intéző bizottságnak nevezett 17 fős (esetleg nagyobb létszámú) szükebb testületet hozott létre, melynek bizonyosan tagja lett Zombori Lajos asztalos, Kiss Ernő cipőfelsőrészkészítő, Szőnyi Imre földműves, Lukács Pál üveges-képkeretező, Erdei Imre földműves, ${ }^{65}$ Csuthy Gizella pedagógus, Böjti András gépgyári raktáros, Fazekas Lajos rendőr őrnagy, városi rendőrkapitány, dr. Szilágyi Géza orvos és Simon József játékkészítő-kisiparos, ${ }^{66}$ rajtuk kívül valószínüleg Szemere Manó, a Makói Háziipari Szövetkezet korábbi elnöke, Kovács Pál pékmester és dr. Sonkovics Mihály ügyvéd és talán Börcsök Lajos földműves, Zsikai Lajos kőműves, Pál Mihály főhadnagy, a Makó Járási Kiegészítő Parancsnokság tisztje, és Szücs Sándor, a Cipész Ksz. elnöke lehetett az intéző bizottság tagja ${ }^{67}$ Közülük megválasztották tisztségviselőiket is, a bizottság elnöke Zombori Lajos az SZDP volt országgyülési képviselője lett, helyetteseivé Kiss Ernőt az SZDP volt Csanád megyei titkárát és Szőnyi Imrét az FKgP volt Makó városi titkárát választották, míg a titkári teendők ellátásával Simon Józsefet bízták meg, ${ }^{68}$ akit egy 1957-es tanácsi jelentés VB-titkárnak nevezett. ${ }^{69}$

${ }^{62}$ MNL CSML ML 515. a. 1763-2/1957. Az októberi ellenforradalmi események hatása a tanácsszervekre. Földházi Imre VB-elnöke jelentése.

${ }^{63}$ Csongrádmegyei Hirlap I. évf. 8. sz. 1956. november 28. 3.

${ }^{64}$ То́тн 1996. 30-31.

${ }^{65}$ Erdei Imre nemzeti bizottsági és a majd az átvilágításokra létrehozott ötös bizottságban betöltött szerepét kétségtelenül árnyalja az a tény, hogy a megmaradt adatok alapján a forradalom előtt az államvédelmi hatóság beszervezett hálózati embere volt. Mivel az Állambiztonsági Szolgálatok Történeti Levéltárának hálózati nyilvántartásában adatai nem maradtak meg, ma már nem tudható, hogy tevékenysége milyen időintervallumra esett, és ennek volt-e bármilyen köze a forradalomban játszott szerepvállalásához. Ha igen, akkor arról Fazekas Lajos rendőrkapitánynak, a nemzeti bizottság (és az ötös bizottság) tagjának nagy valószínúséggel tudnia kellett, hiszen 1953 után a Belügyminisztériumba integrált és a rendőrséggel összevont államvédelmi feladatok irányításáért és végrehajtásáért járási-városi rendőrkapitányként felelősséggel tartozott. Mindazonáltal Bálint László kutatásai nyomán Erdeiről annyi tudható, hogy igazolható „államvédelmi" ténykedése az ötvenes évek elején a Fehér Gárda-mozgalommal állt összefüggésben, és kapcsolattartója Kallós Lajos államvédelmi hadnagy volt. BÁLINT 2017. 253.

${ }^{66}$ ÁBTL 3. 1. 9. V-145872. Fazekas Lajos vizsgálati dossziéja. Fazekas Lajos kihallgatási jkv., 1958. január 24.

${ }^{67}$ A nemzeti bizottság intéző bizottsága tagjainak pontos összetételéről nem áll rendelkezésre eredeti dokumentum, így a megmaradt adatok és a nemzeti bizottság október 31-ei ülésének jegyzőkönyve, továbbá az 1956. november 21-én újból létrehozott VB-be beválasztott nemzeti bizottsági tagok (Csuthy Gizella, dr. Szilágyi Géza és Szűcs Sándor) neve alapján próbáltuk meg valószínűségi alapon rekonstruálni az intéző bizottság névsorát. Lásd még BÁLINT 2006.57.

${ }^{68}$ MNL CSML ML 515. a. 1763/1957. Földházi Imre VB-elnök jelentése.; TóTH 1996. 34-35.; lásd még BÁLINT 2006. 57-58.; FARKAS 2003. 217.

${ }^{69}$ MNL CSML ML 515. a. 1763/1957. Jelentés-tervezet. 3. 
Tekintettel arra, hogy a nemzeti bizottság megválasztásakor már a kommunista állampárt képviselői nem voltak a jelöltek között, az MDP-pártfunkcionáriusok azt a stratégiát választották, hogy tömegesen és szervezetten küldték a téeszelnökök és téeszpárttitkárok szervezésében a termelőszövetkezeti dolgozókat a nagygyülésre ${ }^{70}$ azzal az indoklással, hogy itt kell megvédeniük a szövetkezeti földeket az esetleges földvisszaadást pártolók megválasztásának megakadályozásával, de valójában arról volt szó, hogy ezzel az erővel akarták biztosítani, hogy a nemzeti bizottság személyi összetétele - az eredeti kevéssé optimista koncepciónak megfelelően még számukra elfogadható maradjon. Ezt a célt sikerült elérniük, bár az is tény, hogy ilyen erődemonstrációra valójában nem volt szükség, mert az új jelöltlistán igazán radikális célokat megfogalmazók jószerivel nem is kaptak helyet. Ennél a pontnál azonban érdemes egy kicsit részletesebben elidőznünk.

Mint korábban jeleztük, az MDP városi pártbizottságának kettős elvárása volt a nemzeti bizottság leendő összetételét illetően. Egyrészt célja volt, hogy saját funkcionáriusait juttassa pozícióba, illetve ha erre nem lesz mód, akkor legalább azt próbálja megakadályozni, hogy radikális személyek kerüljenek be az új néphatalmi szervbe. Tekintettel arra, hogy a meghiúsult október 29-ei választást követően a jelölések koordinálása az SZDP és az FKgP helyi politikusai kezébe tolódott át, rajtuk múlott, kiket és hogyan engedtek fölvenni a listára. Utóbb, a forradalom leverését követően B. Papp Mihály VB-elnökhelyettes sértett hangon ecsetelte a városi tanács 1957. március 12-ei ülésén, hogy az SZDP képviselői nem álltak ki a kommunisták mellett, hanem saját embereiket csempészték be ${ }^{71}$ arról azonban nem tett említést, hogy összességében mégis ők akadályozták meg a bizottság összetételének „,radikalizálódását”.

Alátámasztja állításunkat az imént már említett 1959-es Csongrád megyei rendőrségi „Monográfia” is. Az ebben összegyüjtött nevek csoportosításakor a többségükben a volt ÁVH állományából verbuvált politikai nyomozók kiemelt figyelmet fordítottak azokra a szereplőkre, akiket múltjuk alapján be tudtak illeszteni abba a prekoncepcióba, amelyet az ún. ellenforradalom kirobbantóiról, illetve a mögöttes erőkről fölmutatni szerettek volna. ${ }^{72}$ Ily módon azokat, akik ebbe a prekoncepcióba beilleszthetők voltak, külön kiemelték és föltüntették nevük mellett ezt a bizonyos negatív jelzőt (nyilas, horthysta tiszt, kulák, csendőr stb.) az „ellenforradalmi eseményekben" játszott szerepük rövid összefoglalásakor, már ha volt nekik ilyen egyáltalán.

Mint föntebb említettük, a makói nemzeti bizottság tagjainak összegyüjtésekor a szegedi állambiztonsági nyomozók összesen 87 nevet azonosítottak. Ebből mindössze 16 személy nevét és „,bünlajstromát” emelhették ki. Ha ebből leszámítjuk azokat a szociáldemokrata, kisgazda

${ }^{70}$ MNL CSML ML 515. a. 1763/1957. Földházi Imre VB-elnök jelentése.; TóTH 1996. 34.; TAMASI 1981. 44-45.

${ }^{71}$ MNL CSML ML 501. a. Makó Tü. jkv. 1957. március 12. B. Papp Mihály VB-elnökhelyettes beszámolója.

${ }^{72}$ A kimutatás összeállításakor a dr. Nezvál Ferenc igazságügyminiszter, Biszku Béla belügyminiszter és dr. Szénási Géza legfőbb ügyész által 1958. január 8-án kiadott A büntetőpolitikánk egyes kérdéseiről címet viselő 103/1958. számú közös utasítás volt érvényben, mely szerint ,, a bünüldözés súlyát az osztályidegen, deklasszált, huligán elemek és a szokásos bünözök által elkövetett, valamint a súlyosabb természetü büncselekményekre kell fordítani”. SoLT et al. 1995. 796. Azt hogy az osztályidegenek és deklasszált elemek közé kiket soroltak, a belügyminiszter, az igazságügyminiszter és a legfőbb ügyész 1958. október 16-án kiadott 9/1958. BM. száma alatt együttes utasítása rögzítette. Eszerint osztályidegennek tekintették mindazokat, akik kizsákmányolásból éltek (volt tőkések, gyárosok, üzemtulajdonosok, nagykereskedők, bérháztulajdonosok, vállalkozók, arisztokraták, földbirtokosok és kulákok), valamint a főjegyzőig bezárólag mindazok, akik 1945 előtt az államapparátusban vagy állami intézményekben vezető beosztást töltöttek be. Külön kategóriába sorolták a volt horthysta politikai rendőrség minden beosztottját, a rendőrség és a honvédség hivatásos állományába tartozókat, a VKF/2 vezetőit, tisztjeit és beosztottait, valamint a jobboldali pártok és szervezetek vezetőit és országgyülési képviselőit. Harmadik kategóriát, az ún. deklasszált elemeket alkották azok, akik az előbbi két kategóriába nem tartoztak bele, így például az egyházi személyek, papok, urasági intézők. SolT et al 1995. 882.; Lásd még Mıкó 2016. 259-260. 
és parasztpárti vezetőket, akik elsősorban funkciójuknál fogva voltak tagjai a nemzeti bizottság vezető testületének (Id. Zombori Lajos, Kiss Ernő, Szőnyi Imre és Erdei Imre), továbbá kivesszük Fazekas Lajos rendőrkapitányt, akinek a szerepe más megítélés alá esett, akkor a „,reakciósok” listáján összesen 11 személy maradt. Ebből egy volt nyilas párttagot (Simon József), egy volt horthysta tisztet (dr. Bogdán József fogorvos), egy volt csendőrőrmestert (Zsikai Lajos), valamint 8 kulákot (Tóth Gyula, Fazekas János, B. Szűcs Sándor, Kenéz József, Börcsök Lajos, Gazdag Péter, Kovács László és Hinkó Ferenc) tudtak beazonosítani, közülük hat fővel szemben még a legenyhébb eljárást sem tudták megindítani, mivel - ahogyan a dokumentum fogalmazta - ,ellenforradalmi tevékenysége nem volt". ${ }^{73}$ Aligha volt helytálló tehát Glemba Pál városi párttitkár utólagos - korábban már idézett - vádja, miszerint ,, $a$ »Nemzeti bizottság « döntő többsége osztályidegen, illetve ellenséges elemekböl tevödött össze". ${ }^{74}$

Ugyancsak cáfolja Glembát a Szegedi Rendőrfőkapitányság politikai nyomozói által összeállított, s föntebb már szintén hivatkozott másik lista (Összefoglaló a forradalmi bizottságokról) is, amely név szerint mindössze 21 személyt említ meg a makói nemzeti bizottság tagjai közül. A két összeállítás csupán 9 ponton egyezik (id. Zombori Lajos, Kiss Ernő, Szőnyi Imre, Erdei Imre, Fazekas Lajos, dr. Bogdán József, Tóth Gyula, Fazekas János és Kenéz József), a többi ponton eltérések találhatók. Az ebben a listában kiemelt személyek többségükben a nyilvántartás összeállításakor gyakorolt, tehát már a megtorlás következményeit is mutató foglalkozásuk föltüntetésével a következők: Lukács Pál üveges és képkeretező, Vajda Imre munkaügyi előadó (akit, mint föntebb már érintettük, valószínűleg nem is választottak meg ${ }^{75}$ ), Böjti András munkanélküli (utóbb téglagyári segédmunkás), Papp József volt rendőr hadnagy (utóbb kőművessegéd, majd iskolai gondnok), Csuthy Gizella pedagógus, Pál Mihály volt honvéd főhadnagy, Budai József volt honvéd főhadnagy, Békési János tanuló, Zombori Béla asztalos, dr. Kiss Sándor földműves és Keresztúri József kombájnvezető. ${ }^{76}$

Ha itt is megvizsgáljuk a fölsorolt neveket, akkor megállapíthatjuk, hogy az ide fölvett és a másik listán nem szereplő személyek közül egyetlenegyet sem találhatunk, aki megfelelt volna az állampárti bűnbakképzés prekoncepciójának, az említett 11 személy közül 6 volt munkásszármazású, 2-2 kisparaszti és értelmiségi családból érkező és mindössze a szociáldemokrata Lukács Pálnál tudták hozzátenni, hogy kisiparos volt. Származásuk mellett addigi életútjukban sem volt fölfedezhető semmi rájuk nézve terhelő körülmény. Az itt megjelöltek közül a megtorlás részeként a három fegyveres testületi tagot (Papp Józsefet, Pál Mihály és Budai Józsefet), valamint Csuthy Gizellát büntették állásvesztéssel, négy személy ellen nem indítottak semmilyen eljárást (Böjti András, Vajda Imre, ${ }^{77}$ dr. Kiss Sándor és Keresztúri József), egy személy disszidált (Békési János), és csupán két személlyel szemben foganatosítottak külön vizsgálatot (Lukács Pál és Zombori Béla), de végül büntetőeljárást ellenük sem indítottak. Ráadásul a dokumentumban megjegyzésként az is szerepel, hogy a név szerint megemlített 21 személyen kívül még 69 tagja volt a makói nemzeti bizottságnak, ám ,ezek a személyek vagy a prol[etár]. diktatúra mellett fejtettek ki tevékenységet, vagy teljes passzivitást tanúsitottak”. ${ }^{78}$

\footnotetext{
${ }^{73}$ FEJÉR 2009. 127-129.

${ }^{74}$ ÁBTL 3. 1. 9. V-145872. Fazekas Lajos vizsgálati dossziéja. Glemba Pál tanúkihallgatási jkv., 1958. febr. 11.

${ }^{75}$ ÁBTL 3. 1. 9. V-145872. Fazekas Lajos vizsgálati dossziéja. Fazekas Lajos kihallgatási jkv., 1958. január 24.

${ }^{76}$ ÁBTL 3. 1. 9. V-150355/2. Összefoglaló a forradalmi bizottságokról. 28-31.

${ }^{77}$ Noha Vajda ellen nem indult eljárás, az állambiztonsági szervek utóbb mégis megtaláltak, s nyilvánvalóan az 1956-os makói szerepével összefüggésben 1959-ben az akkor már Szegeden élő Vajdát ,, Várhegyi” fedőnéven beszervezték. 1962-es kizárásáig feladata a ,jobboldali SZDP vezetők tevékenységének felderitése” volt. BÁLINT 2017. $228-229$.

${ }^{78}$ ÁBTL 3. 1. 9. V-150355/2. Összefoglaló a forradalmi bizottságokról. 28-31.
} 
A föntiek alapján jól látható, hogy a nemzeti bizottság összetétele egyáltalán nem volt szélsőséges. Nem csak azért, mert az ebbe körbe sorolhatók száma még az utólagos állambiztonsági nyilvántartások szerint is elenyésző volt (sőt, éppen ellenkezőleg, a passzív közremüködők mellett még olyanok is bekerültek a nemzeti bizottságba, akik bár valószínüleg nem voltak az MDP tisztségviselői vagy tagjai, de a kommunista ideológia elfogadói és támogatói voltak), hanem főként azért, mert - mint lentebb látni fogjuk - nem is fogalmazódtak meg radikális követelések a nemzeti bizottságon belül. E tekintetben tehát a kommunista funkcionáriusok második, kevésbé optimista célkitűzése, köszönhetően nem kis részben az általuk utólag elítélt szociáldemokrata pártvezetőknek, maradéktalanul teljesült.

\section{A VÁROSI NEMZETI BIZOTTSÁG MŰKÖDÉSE}

Miután az új népképviseleti szerv október 30-án hivatalosan is megalakult, a nemzeti bizottság átvette a volt városi tanács funkcióit, míg az intéző bizottság (bár formálisan csak másnap) a VB helyére lépett. Miként egy 1957-es jelentés rögzítette: „Általában a Nemzeti Bizottság látott el minden oly funkciót, melyet a tanács, vagy a Végrehajtóbizottság [sic!] hatáskörébe utal a tanácstörvény. E bizottság látta el a VB függetlenített tagjaira háruló feladatokat is."79 Még ezen a napon a bizottság elfogadott egy öt pontból álló kiáltványt, amely a rend helyreállítására szólított fel, a parasztságot és az elkobzott ingatlanok tulajdonosait türelemre intette földjeik és más vagyontárgyaik jogos visszaszolgáltatása törvényes útjának megteremtéséig, továbbá az élelmiszerellátás biztonságát és az áremelésektől való tartózkodást szorgalmazta. ${ }^{80}$ Ugyanezen a napon Szilágyi László aláírásával (akinek neve nem szerepelt a nemzeti bizottság beterjesztett 70 fős listáján és kilétéről sem tudunk semmit) a nemzeti bizottság meg nem nevezett paraszt képviselői is kibocsátottak egy nyilatkozatot, amely egyébként az október 28-ai makói parasztgyülés követeléseinél lényegesen visszafogottabb hangvételü volt és amelyben többek között a volt gazdasági egyesületi épület visszaadását kérték, továbbá követelték, hogy „,az elmúlt tíz év sérelmes dolgait (adó, beszolgáltatás, földkérdések) a lehetőséghez képest időben és mindenki megelégedésére rendezzék" ${ }^{81}$ Szintén ekkor került sor még egy szimbolikus határozat elfogadására: a nemzeti bizottság utasította a makói posta vezetőjét, hogy ,, a kezelésébe tartozó vezetékes rádiók müsorszórását azonnali hatállyal állitsa át időközönként a győri és miskolci adók müsor sugárzására". ${ }^{82}$ Erre azért lett volna szükség, mert az előző napokban sokszor ellentétes hírek jutottak el a budapesti rádión keresztül az országban történtekről Makóra is, és nyilván fontosnak tartották, hogy minél szélesebb és így minél teljesebb körü információhoz jussanak, többek között a vidék történéseiről is. Ezt az intézkedést azonban a postai müszerészek nem tudták végrehajtani ${ }^{83}$ az akkori technikai föltételek valószínűleg nem tették lehetővé, hogy a győri és miskolci adók jelét fogni tudják.

A Makó Város Nemzeti Bizottsága Intéző Bizottsága október 31-én foglalta el a városi tanács épületét és ekkor vette át a felügyeleti és irányítási jogosítványokat a közigazgatási apparátus

\footnotetext{
${ }^{79}$ MNL CSML ML 515. a. 1763-2/1957. Az októberi ellenforradalmi események hatása a tanácsszervekre. Földházi Imre VB-elnök jelentése. 1.

${ }^{80}$ Tо́тн 1996. 7-8. Makó Város Nemzeti Bizottságának kiáltványa.

${ }^{81}$ JAM TD. 75. 181. 1. Földházi Imre VB-elnök jelentésének melléklete; TóTH 1996. 11-12. A makói nemzeti bizottság paraszt képviselőinek fölhívása. Az országban szinte mindenütt megmozdult a vidéki parasztság, és hasonló követeléseket fogalmazott meg. Erről bővebben lásd VARGA 2006. 94-100.

${ }^{82}$ То́тн 1996. 9. A nemzeti bizottság határozata a vezetékes rádiók műsoráról.

${ }^{83}$ MNL CSML SZL XXV. 9. SZMB. B. I. 608/1957. Kovács János és társai pere. Jegyzőkönyv a Kovács János és társai ellen indított bűnügyben 1957. június 26-28-án megtartott tárgyalásról. 18. Szücs Ferenc távbeszélö technikus tanúvallomása.
} 
fölött is, amelynek tagjai közül - a tömeg korábbi követelése ellenére - nem bocsátottak el senkit, sőt, az apparátus előtt fölszólaló nemzeti bizottsági vezetők (Zombori Lajos, Lukács Pál, Szőnyi Imre) közül mindenki úgy fogalmazott, hogy ha valaki nem követett el bűnt vagy visszaélést a pozíciójában és akár meggyőződésből, akár utasításra látta el a munkáját, de azt tisztességesen végezte, annak semmiféle bántódása nem eshet. ${ }^{84}$ Zombori Lajos elnök bemutatkozó beszédében egyenesen azt mondta: „, Kijelentem, hogy nem engedem meg, de a Nemzeti Bizottság egyetlen tagja sem engedi meg, hogy [annak] a szellemi dolgozó[nak], aki ennek a városnak ügyeit intézte - akár meggyözödése szerint, akár parancsra, akármilyen formában, de becsülettel elvégezte, nem nyúl az emberi érzések becstelenségéhez - bántódása legyen, és nyugodtan hajtsák fejüket éjszakai pihenöre." ${ }_{85}$ Kétségtelen, hogy szavai megnyugtatóan hatottak az ott dolgozókra, különösen, hogy a kisgazda Szőnyi Imre is hasonlóan fogalmazott.

A nemzeti bizottság érdemi munkát gyakorlatilag csak az október 31-én tartott ülésén végzett, azt követően számottevő intézkedésekre és döntésekre nem került sor annak ellenére, hogy tudjuk, a következő napokban is tartottak üléseket, bár azokról jegyzőkönyv, följegyzés vagy emlékeztető nem áll rendelkezésünkre. ${ }^{86}$ Mivel az október 31-ei ülés jegyzőkönyve - ha némi hiánnyal is megmaradt, ${ }^{87}$ rekonstruálni lehet a nemzeti bizottság e napi ténykedését. Ami elsőre szembetűnik, az a hozzászólások hangneme, melyekben nyoma sincs a forradalmi radikalizmusnak, inkább a koalíciós idők békülékeny és együttmüködést kereső hangja érzékelhető, miként ez a volt tanácsi apparátus tagjainak eskütételén elmondott, s föntebb jelzett beszédekből is kiderült. Ez a békülékenység a javaslatok fölötti eszmecserében is tetten érhető volt. Amikor Szemere Manó bizottsági tag pl. azt indítványozta, hogy egyelőre hagyják függőben a kormány elismerését, vagy hogy az MDP által igénybevett és feleslegessé váló helyiségeket a nemzeti bizottság ,, az égető lakásigények kielégitésére forditsa", valamint javasolta, hogy az ott található iratokat vizsgálják át és amíg erre sor nem kerül, az irodákat a rendőrség pecsételje le, Kiss Ernő alelnök kifejtette: „Maga részéröl a jelenlegi kormányt elismeri, s annak törvényeit tartja be. A demokratikus pártok közé tartozik a Magyar Kommunista Párt is [sic!], és éppen ezért véleménye az, hogy a 45-ös alkotmány alapján ${ }^{88}$ a rendőrhatóság egy párt helyiségében sem tarthat kutatást, s a Nemzeti Bizottság nem küldhet rendörhatóságot egy párt helyiségébe sem." ${ }^{99}$

${ }^{84}$ TóтH 1996. 12-15. Jegyzőkönyv a makói nemzeti bizottság október 31-ei üléséről.; BÁLINT 2006. 60.; TAMASI 1981. 45. Földházi Imre VB-elnök jelentése szerint a városi tanács személyzeti előadóját a Nemzeti Bizottság hivatalának elhagyására szólította föl, ezt azonban más forrásunk nem erősítette meg. Lásd: MNL CSML ML 515. a. 1763/1957. Földházi Imre VB-elnök jelentése.; То́тн 1996. 35-36.

${ }^{85}$ То́тн 1996. 13. Jegyzőkönyv a makói nemzeti bizottság október 31-ei üléséről.

${ }^{86}$ MNL CSML SZL XXV. 9. SZMB B. I. 1152/1957. Hajdú Ferenc és társainak pere. Fazekas János kihallgatási jkv., 1957. október 11 .

${ }^{87}$ То́тн 1996. 12-15., 16-22. Jegyzőkönyv a makói nemzeti bizottság október 31-ei üléséről.

${ }^{88}$ Pontosan nem lehet tudni, Kiss Ernő mit értett „,45-ös alkotmány” alatt. Az 1945-ös választás nyomán megalakult nemzetgyűlés által elfogadott Magyarország államformájáról szóló 1946. évi I. törvény, amelyet „,ideiglenes alkotmánynak” is neveztek, nem érintette ezt a kérdést. Csupán föltételezzük, hogy a Magyar Nemzeti Függetlenségi Front pártjai (Független Kisgazda-, Földmunkás- és Polgári Párt, Magyar Kommunista Párt, Szociáldemokrata Párt és Nemzeti Parasztpárt) által 1945. január 19-én Debrecenben kiadott Kiáltványra gondolt, amely többek között kinyilvánította: „A pártok a Magyar Nemzeti Függetlenségi Frontban békés együttmüködésre szövetkeztek és egymás szervezkedési szabadságát kölcsönösen tiszteletben tartják és biztositják. Ennek helyi szervezeteikben is érvényt szereznek és eljárnak mindazok ellen, akik a szabad szervezkedést gátolják.” Közli Délmagyarország II. évf. 24. sz. 1945. január 31.1. A közleményt néhány nappal később leközölte a makói kommunisták lapja, a Makói Népújság is. Makói Népújság I. évf. 15. sz. 1945. február 9. 1. Kiss Ernő egyébként tagja volt az 1944. december 21-én Debrecenben megalakult Ideiglenes Nemzetgyülésnek, tehát pontos tudomása lehetett az akkori pártok közötti együttmüködésről és egyezségekről. VIDA 1994. 225-226.

${ }^{89}$ То́тн 1996. 17. Jegyzőkönyv a makói nemzeti bizottság október 31-ei üléséről. 
Kiss Ernő álláspontja valóban vitát váltott ki a nemzeti bizottság jelen lévő tagjaiból. A megmaradt jegyzőkönyvek alapján ez volt az egyetlen olyan indítvány, amely egyértelműen megosztotta a bizottság tagjait. A jegyzőkönyv szerint Kiss Ernő érveivel szemben „A hozzászóló bizottsági tagok elmondják, hogy tények bizonyitják, hogy a Magyar Dolgozók Pártja becsapta a magyar népet. A Nemzeti Bizottságnak kötelessége felfedni az ott történt cselekedeteket, mert feltételezhetö, hogy vannak olyan adatok, amelyeket napfényre hozhatnak. Helyeslik, hogy a bizottság helyeztesse zár alá az összes irattári anyagot." ${ }^{90}$ A többségi álláspont határozattá formálódott, jól mutatva, hogy a bizottság tagjainak nagyobb része szembe kívánt nézni az elmúlt évek történéseivel, ugyanakkor e szembenézési szándékot - legalábbis a jegyzőkönyv ezt nem tükrözte - nem kísérte semmiféle agresszív leszámolási akarat. A bizottság tagjait a jegyzőkönyv tanúbizonysága alapján a megismerés vágya és nem a bosszú vezérelte.

Habár a bizottság - Kiss véleményével szemben - elfogadta az MDP iratanyagának (azaz irodáinak) rendőrségi lepecsételtetését és ezt Fazekas Lajos rendőrkapitány feladatává tette, ennek végrehajtására mégsem került sor, pedig ez a gesztusértékű cselekedet akár egyfajta szakítást is jelképezhetett volna a pártállami múlttal. Van ugyanis adatunk arra, hogy amikor november 2-án Kendi József a Szegedi Városi Nemzetőrség ún. ,egyetemi tizenhármak” nevü csoportjának parancsnoka és tagjai fegyverek után kutatva házkutatást tartottak a két makói pártbizottságon, akkor a járási pártbizottságon iratokat égető funkcionáriusokat, míg a városi pártbizottságon tanácskozó aktivistákat találtak. ${ }^{91}$ Szó sem volt tehát az állampárti iratok lefoglalásáról és az MDP irodáinak lepecsételéséről. E mögött egyébként Fazekas Lajos rendőrkapitány bojkottja állt, aki arra hivatkozással, hogy az intézkedést törvénytelennek tartja, nem hajtotta végre a nemzeti bizottság határozatát. ${ }^{92}$ A nemzeti bizottsági határozat végrehajtásának negligálása tehát azt a lehetőséget biztosította a pártbizottságok funkcionáriusai számára, hogy elszámolás helyett megsemmisíthessék irattáraik tekintélyes részét, köztük azokat a kompromittáló iratokat és káderanyagokat is, melyek megvilágíthatták volna a nemzeti bizottság tagjai és a város lakói előtt a Rákosi-rendszer makói pártapparátusának korábbi machinációit, de megteremtette egyúttal számukra azt a lehetőséget is, hogy a háttérben többé-kevésbé védett és biztonságos körülmények között folytathassák tovább forradalomellenes szervezkedésüket.

A nemzeti bizottság egyéb döntéseket is hozott. Többek között hozzájárult ahhoz, hogy az SZDP makói szervezete visszakaphassa egykori székházát, hogy a FKgP megkaphassa a volt gazdasági egyesületi épületet és támogatta azt is, hogy a hagymakertészek hozzájuthassanak a hagymaház épületében egy helyiséghez. ${ }^{93}$ A Szegedi utcai általános iskolát igazgató Csuthy Gizella kérésére döntést hoztak arról, hogy az iskolához tartozó épületet, melyet a Makói Járási Kiegészítő Parancsnokság (ahogy ő fogalmazta: a Katonai Parancsnokság) használt, visszaadják az oktatás céljaira. ${ }^{94}$ Szemere Manó indítványát továbbgondolva - aki azt javasolta, hogy „a város területén lévő súlyponti vállalatok szövetkezetek és egyéb szervek munkáját, müködését, vezetöit vizsgálják felül, s a politikailag megbizhatatlan vezetőket váltsák le" -, de konkrétan Zombori Béla és Lukács Pál kezdeményezésére „,Kimondja a bizottság, hogy a kulcspozícióban

\footnotetext{
${ }^{90}$ Tóтн 1996. 17. Jegyzőkönyv a makói nemzeti bizottság október 31-ei üléséről.

${ }^{91}$ MNL CSML SZL XXV. Szegedi Katonai Ügyészség iratai. c. Büntető iratok. B. II. 1246/1957. Lazur Barna és társai anyaga. Kendi József kihallgatási jkv., 1957. szeptember 11.; MNL CSML SZL XXV. Szegedi Katonai Ügyészség iratai. c. Büntető iratok. B. II. 1113/1957. Lipták Mihály ügye. Bónus Pál tanúkihallgatási jkv., 1957. augusztus 23.

92 ÁBTL 3. 1. 9. V-145872. Fazekas Lajos vizsgálati dossziéja. Fazekas Lajos kihallgatási jkv., 1958. január 24.

${ }_{93}$ То́тн 1996. 19. Jegyzőkönyv a makói nemzeti bizottság október 31-ei üléséről.

${ }^{94}$ То́тн 1996. 20. Jegyzőkönyv a makói nemzeti bizottság október 31-ei üléséről.
} 
lévő személyek felülvizsgálására 5 tagú igazoló bizottságot alakit. A bizottságba Fazekas Lajos [rendőrkapitány], Erdei Imre [földműves], dr. Soós Antal [volt városi tűzoltóparancsnok], Pápay Endre [tanár] és Böjti András [gépgyári raktáros] Nemzeti Bizottsági tagokat választja." 95 Nyilván e felülvizsgálathoz kapcsolódott azon nemzeti bizottsági határozat, amely az intézményeknél lévő ,,káderanyagok beszolgáltatását” célozta volna, ${ }^{96}$ végrehajtására azonban idő hiányában nem került sor.

Mind közül talán a legfontosabb bizottsági határozat arra irányult, hogy „, az összes kint levö fegyvertartási engedélyeket megvonja. Megbízza fentiek alapján a Rendörkapitányság Vezetőjét, hogy gondoskodjon az összes kint lévö fegyvertartási engedélyek bevonásáról” ${ }^{97} \mathrm{E}$ döntés mögött nyilván nem csak az engedélyek összeszedésének, sokkal inkább a fegyverek begyüjtetésének szándéka húzódott meg, hiszen éppen ezek az engedélyek legitimálták az egykori kiemelt káderek fegyvertartásának jogát, amely kétségtelenül veszélyforrást jelentett azzal együtt is, hogy a megyei pártbizottság utasítására október 28-án bevonták azokat a fegyvereket a járási és városi pártbizottság épületéből, amelyeket még október 24-én részben a rendőrségtől (MÖHOSZ-fegyverek ${ }^{98}$ ), részben a megyei pártbizottságtól (honvédségi fegyverek) kaptak, illetve ekkor bevonásra kerültek a pártfunkcionáriusok személyi fegyverei is, mivel a november 2-án a pártbizottságok helyiségeiben fegyverek után kutató szegedi ,, egyetemi tizenhármak” tagjai ilyeneket már nem találtak. ${ }^{99}$ A rendőrkapitányság illetékesei a még kint lévő személyi használatú fegyverek bevonását a nemzetőrök közreműködésével a szegedi Kendi-féle csoport makói akcióját követően, november 3-án kezdték meg (ügyészség, pénzügyőrség). ${ }^{100}$

Ha csak egy röpke epizód erejéig is, de az október 31-ei ülésen tetten érhető volt a bizottság tagjainak ambivalens viszonya a város lakosságát erősen megosztó termelőszövetkezeti rendszerhez. Miközben a közellátás zavartalanságának biztosítása érdekében határozatot hoztak arról, hogy „A város területén lévő s ez ideig a termelőszövetkezetek használatát képezett darálókat a volt tulajdonosoknak használatra átengedi. [...] 1956. november hó 1-töl kötelesek a darálósok üzemeiket

${ }^{95}$ Tóтн 1996. 16., 20-22. Jegyzőkönyv a makói nemzeti bizottság október 31-ei üléséről., Az öt tag közül egyedül Pápai Endre neve nem szerepel az október 30-án megválasztott 70 fős nemzeti bizottsági listán, viszont tudjuk, hogy őt Vida Zoltán és Csuthy Gizella mellett a pedagógusok forradalmi szerve delegálta a nemzeti bizottság tagjai közé. A Fazekas Lajos volt rendőrkapitány egyik kihallgatási jegyzőkönyvéből szerzett adatunk szerint az ötös bizottság mindösszesen egy esetben, Oravecz István járásbírósági elnök kapcsán végzett átvilágítást. ÁBTL 3. 1. 9. V-145872. Fazekas Lajos vizsgálati dossziéja. Fazekas Lajos kihallgatási jkv., 1958. január 24. Ennek alaposságáról, eredményéről és következményeiről azonban nem rendelkezünk információval. Ellenben azt tudjuk, hogy Oravecz a forradalom napjaiban nem volt Makón (a hivatalos verzió szerint ,,1956-ban az ellenforradalom idején eltávolitották a munkahelyéröl, ezen idő alatt Nagylakon tartózkodott", a nem hivatalos verzió szerint hazamenekült Nagylakra), tehát személyesen szinte bizonyosan nem vett részt a procedúrában, így nem is védekezhetett az esetleges terhelő adatokkal szemben. Oraveczről lásd MNL CSML SZL XXXIII. 3. MSZMP Archívum. 9. MSZMP Makó Városi Bizottsága iratai. Káderanyagok 1957-1989. Oravecz István dossziéja. Jellemzés, 1959. júl. 17.; MSZMP Archívum 1. MSZMP Csongrád Megyei Bizottsága iratai. 3. 13. ő. e. Dr. Strohner Ferenc levele, 1957. augusztus 5.

${ }_{96}^{6}$ ÁBTL 3. 1. 9. V-145872. Fazekas Lajos vizsgálati dossziéja. Fazekas Lajos kihallgatási jkv., 1958. január 24.

${ }^{97}$ То́тн 1996. 22. A nemzeti bizottság határozata a fegyverviselési engedélyek bevonásáról.

${ }^{98}$ A Magyar Önkéntes Honvédelmi Szövetség (MÖHOSZ) egy paramilitáris szervezet volt, melyet különböző szervezetek egyesítéséből 1955-ben hozták létre. A Kádár-rendszer Magyar Honvédelmi Szövetsége (MHSZ) jogelődjének tekinthető.

${ }^{99}$ MNL CSML SZL XXV. Szegedi Katonai Ügyészség iratai. c. Büntető iratok. B. II. 1246/1957. Lazur Barna és társai ügye. Kendi József kihallgatási jkv., 1957. szeptember 11.; BÁLINT 2006. 23., 43., 75-77.

${ }^{100}$ MNL CSML SZL XXV. 9. SZMB B. I. 1152/1957. Hajdú Ferenc és társainak pere. B. I. 1152/1957/6. szám. Jegyzökönyv a Hajdú Ferenc és társai ellen indított bünügyben 1957. november 28-29-én megtartott tárgyalásról. 9-10.; ÁBTL. 3. 1. 9. V-145872. Fazekas Lajos vizsgálati dossziéja. A Szegedi Katonai Bíróság B. II. 64/1958. számú itélete; BÁLINT 2006. 86-87. 
üzemeltetni, úgy mintha az magántulajdont képezne, kötelesek továbbá a megfelelö könyvelést vezetni.", tehát visszaadták müködtetésre az elvett, egykor magántulajdonban lévő malmokat volt tulajdonosaiknak, aközben a vitához hozzászóló kisgazda Szőnyi Imre a malmok tulajdonjogának visszaadása ügyében arról beszélt, hogy ,,nem tartja illetékesnek a bizottságot arra, hogy ez ügyben - már mint a darálók visszaadásában - döntsenek, s így javasolja azt nem elfogadni, mivel azt törvényes rendelkezések fogják szabályozni”. ${ }^{101}$ Egy másik vita kapcsán a bizottság ülésén az állambiztonsági szolgálatok 1959-es ,,monográfiájában” egyébként kuláknak minősített és a kisgazdapárt újjászervezésébe bekapcsolódó Börcsök Lajos bizottsági tag javaslatára rögzítették, hogy ,, a tsz-ektöl semmiféle élö állatot, gazdasági felszerelést senki el ne vihessen addig, amíg ezzel kapcsolatban a felsöbb szervek részéröl intézkedés nem történik" ${ }^{102}$

A két döntés (a malmok használati jogának visszaadása a régi tulajdonosának, ugyanakkor azok tulajdonjogának meghagyása a termelőszövetkezeteknél) látszatra eltérő akaratnyilvánítást mutat, még sincs közöttük logikai ellentmondás. A darálómalmokat az akkor mindennél fontosabb közellátás biztonságos fönntartása érdekében kellett elvenni a szövetkezetektől, mert félő volt, hogy azok esetleges leállása ellátási zavarokhoz vezetett volna. De azokban a döntésekben (így az erőszakkal elvett termelőszövetkezeti vagyontárgyak visszaszolgáltatása ügyében), melyek nem voltak sürgetőek, mindenáron meg akarták várni a törvényes rendezést és ebben a utóbb legreakciósabbnak minősített , kulákok” voltak a legkövetkezetesebbek. Éppen Börcsök Lajos és előtte Szőnyi Imre volt városi kisgazdapárti titkár (aki egyébként a koalíciós időszakban a leghatározottabban kiállt a malmok államosítása ellen ${ }^{103}$ ) nemzeti bizottsági hozzászólása és javaslattétele mutatta a legeklatánsabban, hogy az a vád, amellyel a kommunisták riogatták a termelőszövetkezeti dolgozókat, miszerint azonnal elveszik tőlük a földjeiket és az eszközeiket, teljességgel megalapozatlan volt. Ilyen hangok, ilyen hozzászólások, mint a nemzeti bizottsági ülés jegyzőkönyvéből is látható, nem voltak, sőt, ellenkezőleg, a termelőszövetkezeti vagyon egyben tartása melletti javaslat fogalmazódott meg és került elfogadásra arra az időtartamra, amíg a törvényes és jogszerű megoldások nem születnek meg a visszásságok rendezésére. Mint említettük, ez szerepelt a nemzeti bizottság előző napon, október 30-án kiadott kiáltványában is. ${ }^{104}$

Arról, hogy erre lesz törvényes lehetőség, a földek visszaadása ügyében október 29-én a megyei tanács elnökénél tárgyaló makói parasztdelegáció tagjai, Erdei Imre, Fazekas János és Kenéz József hoztak információt. Fazekas János az 1957. november végén zajló perének bírósági tárgyalásán elmondta: „,Erdei Imre [a háromfős makói tárgyalódelegáció egyik tagja - M. A.] ezután telefonon keresztül értekezett a minisztériummal, s onnan kapott utasitás szerint közölte, hogy a minisztérium ezen problémák [tudniillik az erőszakkal elvett földek és egyéb vagyontárgyak visszaadása vagy valós kárpótlása - M. A.] megoldása érdekében egy rendeletet fog majd kiadni, s addig amíg ez meg nem jelenik, mindenki a csereingatlanát mívelje meg. Amikor azután visszaérkeztünk Makóra, közöltük, hogy meg fog jelenni egy országos rendelet, azonban addig ne nyúljon senki sem a közvagyonhoz." ${ }^{105}$ Biztosra vehető tehát, hogy a nemzeti

\footnotetext{
${ }^{101}$ MNL CSML ML 502. a. Makó VB jkv. 1956. november 30. Kivonat Makó Város Nemzeti Bizottsága 1956. október 31-én tartott ülése jegyzökönyvéböl.

${ }^{102}$ То́тн 1996. 19., 26. Jegyzőkönyv a makói nemzeti bizottság október 31-ei üléséről és A nemzeti bizottság határozata a termelőszövetkezetek használatában lévő darálók eredeti tulajdonosoknak történő visszaadásáról.

${ }^{103}$ „A Kisgazdapárt a magántulajdon elvét vallja, éppen ezért ellenzi a malmok községesitését” - jelentette ki Szőnyi Imre 1946 szeptemberében. Idézi TAMASI 1974. 97.

${ }^{104}$ То́тн 1996. 7-8. Makó Város Nemzeti Bizottságának kiáltványa.

${ }^{105}$ MNL CSML SZL XXV. 9. SZMB B. I. 1152/1957. Hajdú Ferenc és társainak pere. B. I. 1152/1957/6. szám. Jegyzőkönyv a Hajdú Ferenc és társai ellen indított bünügyben 1957. november 28-29-én megtartott tárgyalásról. 12.
} 
bizottság kisgazda képviselői ennek a minisztériumi ígéretnek a birtokában fogalmazták meg a jogszerü rendezés kivárásának szükségességét, hiszen nem erőszakos és azonnali, hanem biztos, védhető és tartós megoldásban voltak érdekeltek. A kedélyek lecsillapításában azonban bizonyosan közrejátszott Nagy Imre miniszterelnök október 28-ai rádióbeszéde is, amelyben - többek között - arról beszélt, hogy „A kormány erélyes kézzel véget vet a termelöszövetkezeti mozgalom és a tagositások során elkövetett súlyos törvénytelenségeknek, s nagyszabású tervet dolgoz ki az elhanyagolt és fejlödésében elmaradott mezögazdasági termelésünk fellenditésére, termelöszövetkezeti és egyéni gazdaságok termelésének felvirágoztatására, a termelési kedv helyreállítására." ${ }^{106}$ A makói gazdák várakozással tekintettek a miniszterelnök által kilátásba helyezett ígéretek teljesülése elé.

Nagy Imre bejelentése a termelőszövetkezeti dolgozók számára is megnyugtatóan hatott. A Viharsarok című megyei napilap ezzel kapcsolatban megszólaltatta László Jánost, a makói József Attila Tsz párttitkárát, aki kifejtette: „,Egyetértünk Nagy Imre elvtárssal. Különösen helyeseljük a mezögazdasággal kapcsolatos szavait; azt, hogy a kormány megszünteti az eröszakos tsz fejlesztést és a tagositás eröltetett, törvénysértő módját. Örülünk a nyilatkozatnak azért, mert az utóbbi napokban azt kezdtük hinni, hogy megszünik a szövetkezeti mozgalom. Most már látjuk, hogy ez nem igaz, csak az eröszakos tsz-szervezés szünik meg. Ez helyes. Nincs semmi értelme, hogy eröszakosan szervezzenek szövetkezeteket. Olyan ez, mint a házasélet. Ha a leányt és a legényt eröszakkal kötik egymáshoz, nem lesz belöle boldog család, míg az önkéntes társulást összeforrasztja a közös akarat." ${ }_{107}$

Abban tehát, hogy a következő napokban élesebb konfliktushelyzet már nem alakult ki Makón, bizonyosan közrejátszott, hogy a két egymással komoly érdekellentétben álló csoport tagjai, egyrészt az erőszakos tagosítások és az egyéni gazdálkodás ellehetetlenítése miatt elégedetlen gazdák, másrészt az egzisztenciájukat védő termelőszövetkezeti és állami gazdasági dolgozók is úgy ítélték meg, hogy a kialakult helyzet számukra kedvező, illetve elfogadható. Az előbbiek azt várták, hogy a kormány betartva ígéretét jogi úton fogja rendezni helyzetüket, míg az utóbbiak azt szűrték le a miniszterelnök bejelentéséből, hogy a meglévő termelőszövetkezetek érintetlenül maradnak. Ennek nyomán kialakult egy egyensúlyi helyzet, amelyet a következő napokban nem rúgott föl senki, még akkor sem, ha a kommunista állampárt utasítására az október 30-ai nemzeti bizottsági választáson szervezetten vettek részt a termelőszövetkezeti dolgozók, valós közbeavatkozásukra azonban nem került sor.

Kétségtelen, a nemzeti bizottságnak, illetve az abban helyet foglaló kisgazda képviselőknek a törvényes rendezést váró és addig a szövetkezeti vagyon egyben tartása melletti konzekvens kiállása meghatározó szereppel bírt abban, hogy Makón - szemben a járás több településén tapasztaltakkal egyetlenegy termelőszövetkezet sem bomlott föl, de még a téeszek birtokába került vagyontárgyak is sértetlenül egyben maradtak. Egy 1957 decemberében keltezett tanácsi jelentésnek is el kellett ismernie: „Az októberi események a városi termelöszövetkezetekre nem voltak olyan káros hatással, mint más területeken. A városban lévö termelöszövetkezetek mind megmaradtak és tovább dolgoztak és dolgoznak. De nem gyengültek a tsz-ek azáltal sem, hogy a múlt év [tehát 1956 - M. A.] végén illetéktelenül bárki is igyekezett volna egy-egy tsz gazdasági javait széthordani."108

\footnotetext{
${ }^{106}$ VARGA 1989. 132.; Viharsarok XII. évf. 256. sz. 1956. október 30. 1.

${ }^{107}$ Viharsarok XII. évf. 256. sz. 1956. október 30. 4.

${ }^{108}$ MNL CSML ML 515. a. 7425/1957. A tanácsok pártirányitása és a községfejlesztési feladatok. Jelentés. 3-4. Csupán egy erőszakos földvisszavételi kísérletről van információnk 1957. február végéről, de a hatóságok az érintett termelőszövetkezet följelentése alapján ezt is megakadályozták. Lásd Csongrádmegyei Hírlap II. évf. 52. sz. 1957. március 3. 1.
} 
Mindazonáltal a malmok visszaadásánál (talán nem is tudatosan és minden következményét nem átgondolva, csupán a helyzetre adott gyors válaszként és azonnali döntést hozva) a nemzeti bizottság tagjai már hoztak egy értékválasztást is: míg a termelőszövetkezetek kezében tartva nem látták biztosítottnak a folyamatos üzemelést, addig a volt tulajdonosok kezében megtalálták a müködtetés garanciáját. ${ }^{109}$ Ennek azonban a későbbiekben már nem volt jelentősége.

A nemzeti bizottság október 31-ei ülésén még további fontos döntéseket hozott, melyek az oktatási intézményeket érintették. Vida Zoltán városi tanulmányi felügyelő, a Pedagógusok Forradalmi Tanácsa ötös bizottságának elnöke javaslatára határozatban szólították föl ,valamennyi szerv munkástanácsát a kádernyilvántartással kapcsolatos iratok beszolgáltatására”, továbbá ugyancsak Vida javaslatára határoztak arról, hogy valamennyi iskolában egyöntetüen november 5-ével indítják újra a tanítást (erre végül is már csak a makói forradalom leverését, azaz a város november 9-ei megszállását követően, november 12-én került sor). Határozatot hoztak arról is, hogy leválasztva a járási tanács müvelődési osztályáról, önálló városi oktatási osztályt szerveznek, melynek vezetőjéről a pedagógusok forradalmi bizottsága javaslatának figyelembe vételével később döntenek, ennek realizálására azonban a körülmények megváltozása következtében már nem került sor. ${ }^{110}$

A városban élő kisiparosok szempontjából volt nagyon lényeges a jogtalanul bevont kisiparos és kiskereskedői igazolványok fölülvizsgálatával és az engedélyek újbóli kiadásával kapcsolatos döntés, amelyet az ülésen elsőként Szemere Manó nemzeti bizottsági tag kezdeményezett. Hozzá csatlakozott Kovács Pál pékmester, bizottsági tag is, aki szintén szorgalmazta ,a kisiparosság 12 pontban elöterjesztett követelése" 111 alapján a bevont iparigazolványok fölülvizsgálatát, amivel egyébként a nemzeti bizottság többi tagja is egyetértett. Lukács Pál - maga is kisiparos ehhez kapcsolódóan indítványozta: ,, utasitsa a bizottság az ipari csoport vezetöjét, hogy a beérkezett kérelmek alapján az iparigazolványokat korlátlanul adja ki, annál is inkább, mivel ezzel a kontárok müködése is felszámolható lesz". ${ }^{112}$ A döntés végrehajtásáról kevés adatunk van, érdemi áttörésre ebben idő hiányában nyilvánvalóan nem kerülhetett sor, bár tény, hogy a forradalom napjaiban valóban sor került új iparigazolványok kiadására, tehát a folyamat kezdetét vette. ${ }^{113}$

Foglalkoznia kellett a nemzeti bizottságnak a közellátás kérdéseivel is, különösen amiatt, mert már október 24-étől mind kezelhetetlenebb fölvásárlási láz vette kezdetét a városban, a boltok készlete vészesen megfogyatkozott, utánpótlás beszerzésére pedig nem, vagy alig volt lehetőség. Földházi Imre a városi tanács VB-elnöke 1957. márciusi összefoglalója szerint „,Október 24-én reggel és az azt követö napokban a különbözö hírek hatására megkezdödött a vásárlási láz. A kereskedelmi szervek raktárai már az elsö napon túlnyomó részben kimerültek. Megkezdödött a nagykereskedelmi készletek nagyobb arányú igénybevétele. A kereskedelmi dolgozók ezekben a napokban igen igénybe voltak véve, napi 14 órát is dolgoztak, hogy a hatalmas

${ }^{109}$ Ezt néhány héttel később, a forradalom leverését követően helyreállított tanács végrehajtó bizottsága másként gondolta, ezért a termelőszövetkezetek egybehangzó beadványa nyomán érvénytelenítette a nemzeti bizottság október 31-ei határozatát, és a 162/1956. VB. számú határozatával a József Attila Tsz-nek, a Haladás Tsz-nek, a Köztársaság Tsz-nek és az Új Élet Tsz-nek visszaszolgáltatta az egykor magántulajdonban lévő darálómalmokat. MNL CSML ML 502. a. Makó VB jkv. 1956. november 30.

${ }^{110}$ MNL CSML SZL XXXIII. 3. MSZMP Archívum. 1. Az MSZMP Csongrád Megyei Bizottsága iratai. Fegyelmi ügyek 1957-1983. 85. ő. e. Vida Zoltán fegyelmi ügye. Kivonat az 1956. október 31-én a makói nemzeti bizottság ülésén készült jegyzökönyvböl.

${ }^{111}$ Lásd Tо́тн 1996. 3. A Kisiparosok Országos Szervezete Makói Csoportja Ideiglenes Iparos Tanácsának határozata, 1956. október 28.

${ }^{112}$ То́тн 1996. 16-18. Jegyzőkönyv a makói nemzeti bizottság október 31-ei üléséről.

${ }^{113}$ MNL CSML ML 515. a. 1763/1957. Földházi Imre VB-elnök jelentése.; То́тн 1996. 35. 
forgalmat le tudják bonyolítani. A felvásárlás föleg a só, gyufa, liszt, cukor, petróleum vásárlására irányult nagymértékben. A folyamatos utánpótlást a kereskedelem csak néhány napig tudta biztositani, azután hiányok keletkeztek. A vásárlás később minden árura kiterjedt, nagyobb mérvü iparcikk felhalmozás a pénzzel rendelkezö parasztságtól indult ki, akik között számosan akadtak olyanok, hogy a tüzhelytöl kezdve a porszívógépig minden iparcikket megvettek." 114 Éppen ezért vette vita nélkül tudomásul - külön határozathozatal nélkül - a városi nemzeti bizottság Veszelovszki Illés, a Makó és Környéke Kiskereskedelmi Vállalat munkástanácsa képviseletében bejelentett tájékoztatását, mely szerint a vállalati munkástanács döntése nyomán „az iparcikk boltokat a további intézkedésig zárva tartják a további felvásárlások megakadályozása érdekében. A holnapi napot [november 1-jét], mivel egyházi ünnep van, valamint a halottak napján a gyászra való tekintettel a boltokat zárva tartják, kivéve a hús, kenyér és tej árusitását". ${ }^{115}$ A kenyérellátás biztonságát szolgálta az a nemzeti bizottsági döntés, melynek értelmében a túlterhelt kenyérgyár mellett az akkor kihasználatlanul álló kisiparos pékek kapacitásainak igénybe vételéről döntöttek, akik azért nem tudtak termelni, mert nem, illetve csak korlátozottan jutottak liszthez és tüzelőhöz, miként azt Kovács Pál bizottsági tag, civilben pékmester is fölvetette, aki egyébként - mint a nemzeti bizottság ülésén elmondta - két éve kapta vissza korábban elvett iparát. A magánpékek lisztellátását a kenyérgyár készleteiből biztosították. ${ }^{116}$

Fölvetődtek persze olyan határozati javaslatok is, amelyek meghaladták a városi nemzeti bizottság kompetenciáit. Ilyen volt például a Szemere Manó nemzeti bizottsági tag által szóba hozott indítvány, amely azt célozta, hogy „,tegyék lehetővé a nyugati országok sajtóinak behozatalát”. ${ }^{117}$ Az ilyen javaslatokkal értelemszerüen a nemzeti bizottság érdemben nem tudott mit kezdeni, de jól mutatták azt az igényt, amely a forradalom aktív résztvevői részéről az objektív tájékoztatásra és a lehető legteljesebb nyilvánosság biztosítására irányult. Mindemellett voltak olyan indítványok is, amelyek elfogadásuk esetén nyilvánvalóan nem nyerték volna el a makóiak tetszését. A Makói Vegyesipari Javító Vállalat dolgozói például azt kezdeményezték, hogy a kormányzat a forradalom áldozatainak emlékére ,, az egész ország területére rendeljen egy hat hetes gyászt, mely szerint minden szórakozási és nyilvános hely zárva legyen”. Túl azon, hogy ebben a városi nemzeti bizottságnak nem sok kompetenciája volt, az egyébként nyilvánvalóan kegyeletteljes javaslat még szembe is ment a makóiak akaratával, akik az október 28-ai nagy tüntetésen, amikor kiegyeztek Fazekas Lajos rendőrkapitánnyal, az egyik fő követelésükként a kijárási tilalom megszüntetése mellett a szórakozási lehetőségek újbóli biztosítását, elsődlegesen a mozik újbóli megnyitását fogalmazták meg. Nem véletlen, hogy az ülésen éppen a tüntetőkkel ez ügyben írásbeli megállapodást kötő Fazekas Lajos rendőrkapitány volt az, ${ }^{118}$ aki tompítani igyekezvén a javaslat élét azt kezdeményezte, hogy - ,, mivel véleménye szerint a Vegyesipari vállalat dolgozóinak elöterjesztésével nem lehet a Kormány felé fordulni" - helyben és csak három napos szórakozási korlátozás legyen. ${ }^{119}$ Mivel határozat az ügyben nem született, valószínűsíthető, hogy a Makón újabb békétlenséget vagy konfliktusokat generáló indítvány végül is lekerült a napirendről.

\footnotetext{
${ }^{114}$ MNL CSML ML 515. a. 1763/1957. Földházi Imre VB-elnök jelentése.; TóTH 1996. 38-39.

115 То́тн 1996. 18. Jegyzőkönyv a makói nemzeti bizottság október 31-ei üléséről.

${ }^{116}$ То́тн 1996. 18. Jegyzőkönyv a makói nemzeti bizottság október 31-ei üléséről.

117 Tóтн 1996. 16. Jegyzőkönyv a makói nemzeti bizottság október 31-ei üléséről.

${ }^{118}$ A megállapodás eredeti, Fazekas által aláírt példányát lásd a makói József Attila Múzeum állandó várostörténeti kiállításának az 1956-os eseményeket bemutató vitrinjében (leltári szám nélkül). Fakszimiléje megjelent: Makói História 9. évf. (2006). 2-3. sz. 6.

119 Tóтн 1996. 20. Jegyzőkönyv a makói nemzeti bizottság október 31-ei üléséről.
} 
Az október 31-ei ülését követően a városi nemzeti bizottság intéző bizottsága érdemi tevékenységet nem végzett, noha a következő napokban is tartottak üléseket. A bizottság egyik tagja, Fazekas János később így emlékezett erre: „,Nem tudom, hányan voltunk a Nemzeti Bizottságban, de nagyon rövid életü volt az, csak néhány ülés volt. Kétnaponként tartottunk ülést. Lényegében nem tudtunk csinálni semmit, mert nem hajtottak végre semmit." ${ }^{120}$ Noha a nemzeti bizottság tagjai - még ha formális ülést nem is, vagy csak ritkán tartottak - október 31-ét követően egészen biztosan folyamatosan tárgyaltak, érdemi, nagy jelentőségű döntéseket azonban már nem hoztak, ennek látható nyoma legalábbis nem maradt meg. A bizottság egy fontosabb ügyben még hallatta a hangját: november 2-án kezdeményezték a rendőrkapitánynál, hogy olyan rendőrök ne teljesítsenek szolgálatot, akik korábban részt vettek a tömegek oszlatásában, ${ }^{121}$ az ezzel kapcsolatos formális döntés - már ha volt ilyen egyáltalán - nem maradt meg. Ugyanakkor a bizottság - az október 31-én megalakult Forradalmi Ifjúsági Szövetség (FISZ) tagjaival együttmüködve fontos szerepet töltött be a budapesti élelmiszersegélyszállítmányok szervezésében, ezt egyébként a pozíciójába 1957. március 1-jével visszahelyezett régi-új tanácselnök, Földházi Imre is elismerte egy későbbi jelentésében. ${ }^{122}$ Ennek nagyságrendjéről nincs adatunk, de bizonyosra vehető, hogy nagyjából tucatnyi tehergépkocsi vitte a fóvárosba a makóiak élelmiszeradományait (november 2-án például 6 teherautónyi szállítmányt indítottak útnak ${ }^{123}$ ). Egyik alkalommal a nemzeti bizottság elnöke, Zombori Lajos is elkísérte a konvojt Budapestre. ${ }^{124}$

Habár a nemzeti bizottság és intéző bizottsága a következő napokban dokumentálható munkát nem folytatott (legalábbis erre utaló iratok nem maradtak meg), a napi hivatali ügymenet, különösen a közellátás folyamatosságának biztosítása érdekében, változatlan mederben folyt. Ugyan Földházi Imre VB-elnök 1957. márciusi beszámolójában azt írta: „, Október 31-től kezdve a Városi Tanács Végrehajtóbizottsága [sic!] müködést nem tudott kifejteni. A nemzeti bizottság intézö bizottsága akarta betölteni a VB jogkörét, az elnöki teendöket Zombori Lajos, a titkárit Simon József látta el. A szakigazgatási szervekben változás nem következett be, a dolgozók, az osztályvezetők, sőt a vb titkára [dr. Karsai András - M. A.] is hivatali helyén maradt, de az apparátus semmi hatáskört nem tudott gyakorolni.", ${ }^{125}$ mégis úgy tünik, történt hivatali ügyintézés a forradalom új szervei működési ideje alatt is. Éppen Földházi erősítette meg, hogy az intéző bizottság titkára, Simon József

\footnotetext{
${ }^{120}$ FAZEKAS 2016. 9.

${ }^{121}$ Kiss Ernő a városi nemzeti bizottság elnökhelyettese a Fazekas Lajos rendőrkapitány elleni eljárás során tett tanúvallomásában erről a következőket mondta: „, $A$ »nemzeti bizottság« részéröl nem volt kifogás egy rendőr ellen sem. A lakosság részéröl érkeztek panaszok egy pár rendör ellen - neveikre már nem emlékszem. Ugyanis felmerült, hogy durvák. Ezt figyelembe véve Fazekassal áthozattunk egy névsort és megnéztük, hogy ténylegesen mi a helyzet, szolgálatot teljesitenek-e ezek a rendörök. Két-három fö esetében olyan határozat, illetve megállapodás született, hogy ne teljesitsenek szolgálatot. Arról nem volt szó, hogy ezeket a rendöröket el kell bocsátani. Meg kívánom jegyezni, hogy Fazekas is javasolt egy rendört felfüggeszteni, mert részeges volt és szolgálatát nem látta el megfelelöen. Azt nem tudom, hogy a megállapodás milyen formában lett végrehajtva, ugyanis a rendörség munkáját nem ellenőrizte a »nemzeti bizottság«, mert az nem volt feladata." ÁBTL 3. 1. 9. V-145872. Fazekas Lajos vizsgálati dossziéja. Kiss Ernö tanúkihallgatási jkv., 1958. február 5.; BÁLINT 2006. 73.

${ }^{122}$ MNL CSML ML 515. a. 1763/1957. Földházi Imre VB-elnök jelentése.; TóтH 1996. 40.

${ }^{123}$ Szabad Viharsarok I. évf. 3. sz. 1956. nov. 3. 2. Azt tudjuk, hogy nem csak a nemzeti bizottság és vele együttmüködésben a FISZ tagjai gyűjtöttek és szállítottak Budapest megsegítésére élelmiszeradományt, hanem a földműves szövetkezet, sőt a termelőszövetkezetek is. Ők azonban az adományok célba juttatásáról saját maguk gondoskodtak. MNL CSML ML 515. a. 1763/1957. Földházi Imre VB-elnök jelentése.; Tóтн 1996. 40.; MNL CSML ML 515. a. 1763/1957. Jelentéstervezet. Kereskedelmi rész. 2.

${ }^{124}$ MNL CSML ML 515. a. 1763/1957. Jelentés-tervezet. 1.

${ }^{125}$ MNL CSML ML 515. a. 1763/1957. Földházi Imre VB-elnök jelentése.; Tóтн 1996. 34.
} 
„, benzinjegyeket bélyegzett felül, vágási engedélyeket adott ki, s különböző igazoló írásokat állítottak ki a hozzájuk forduló ügyfelek részére". ${ }^{126}$ Emellett - mint erről már föntebb volt szó - a hivatal ipari csoportja iparengedélyeket adott ki és biztosították - szintén a közellátás folyamatossága érdekében -, hogy a magánpékek is kaphassanak lisztkiutalást. ${ }^{127}$ Ezek az intézkedések egyértelműen arra utaltak, hogy az élet ezekben napokban már kezdett visszatérni a rendes kerékvágásba.

A városi nemzeti bizottság ténykedésének utolsó, forrással is alátámasztható nyomát Makó november 9-ei szovjet megszállását megelőzően november 5-én találtuk meg: a bizottsági tagok ekkor még hoztak egy határozatot, melynek nyomán a postások a Szabad Európa Rádióra állították át a városban müködő vezetékes rádiókat. ${ }^{128}$ Ennek az intézkedésnek az oka nyilvánvalóan a pontosabb tájékozódás igénye volt, tekintettel arra, hogy a Kossuth Rádió a november 4-ei intervenciót követő napokban a Kádár-kormány közleményeinek ismételgetésén túl kizárólag tánczenét sugárzott. ${ }^{129}$

\section{A JÁRÁSI NEMZETI BIZOTTSÁG MEGALAKULÁSA}

A járási nemzeti bizottság létrehozása mögött - a városi nemzeti bizottság kezdeményezéséhez hasonlóan ugyanannak a célnak az elérése érdekében, de attól függetlenül - szintén a volt kommunista állampárt funkcionáriusainak hatalomátmentési kísérlete állt. Október utolsó napjaira a járás majd minden településén létrejöttek az új hatalmi szervek, a helyi nemzeti bizottságok, amelyek különböző fölfogásban és habitussal, de autonóm módon láttak munkához, függetlenítve magukat a korábbi járási tanács gyámkodással fölérő irányítási gyakorlatától. ${ }^{130}$ Ugyanakkor várható volt, hogy hamarosan létre fog jönni egy olyan spontán forradalmi szervezet is, amely a települések közötti koordinációt vállalja magára. Forgó István a járási tanács VB-elnöke és megbízható munkatársai, akik közvetlen támadásnak kitéve nem voltak érintettek a makói eseményekben és formálisan a helyükön maradhattak, a lehetőségeket és esélyeket mérlegelve már október végén arra jutottak, hogy nem szabad megvárniuk a falusi nemzeti bizottságok részéről előbb-utóbb várható spontán - tehát alulról jövő - kezdeményezést, hanem azt megelőzve nekik kell ennek a folyamatnak az élére állniuk. ${ }^{131}$ Ez nem csupán arra volt jó, hogy ezzel egy radikálisabb váltást megelőzzenek, de arra is, hogy a saját maguk irányítói pozícióit megőrizzék. Ez adott magyarázatot arra a kitartó szervező munkára, amelyet november első napjaiban végeztek annak érdekében, hogy a járási nemzeti bizottság választásának ügyéhez minden települést megnyerjenek és onnan delegátusokat szervezzenek. ${ }^{132}$

\footnotetext{
${ }^{126}$ MNL CSML ML 515. a. 1763/1957. Földházi Imre VB-elnök jelentése.; Тóтн 1996. 35.

${ }^{127}$ Tóтн 1996. 18. Jegyzőkönyv a makói nemzeti bizottság október 31-ei üléséröl.; MNL CSML ML 515. a. 1763/1957. Földházi Imre VB-elnök jelentése.; Tóтн 1996. 35.

${ }^{128}$ BALOGH 1993. 53.

${ }^{129}$ MNL CSML SZL XXV. 9. Szegedi Megyei Bíróság iratai. Büntetőperes iratok (SZMB B.) I. 608/1957. Kovács János és társai pere. A nemzeti bizottság november 5-ei utasitásának másolata.

${ }^{130}$ A Makói járás falvaiban létrejövő nemzeti bizottságok megalakulásáról és müködéséről lásd részletesen: MAROSVÁRI 2006.

${ }^{131}$ Forgó utóbb a forradalom (olvasatában ellenforradalom) időszakában végzett tevékenységéről szóló igazoló jelentésében arról írt, hogy a városi nemzeti bizottság fölszólítására kezdek hozzá a járási nemzeti bizottság megszervezéséhez, de ez bizonyosan nem felel meg a valóságnak, inkább arról van szó, hogy a felelősséget kívánta magától hárítani, mivel mégis csak egy forradalmi intézmény létrejöttének élére álltak, még akkor is, ha ezt a hatalomátmentésük céljából, s csupán taktikai megfontolásból tették. MNL CSML ML 202. b. Makói Járási Tanács VB-elnökének iratai. 006/1957. Jelentés. Előkészítő anyag.

${ }^{132}$ MAROSVÁRI 2006. 176-178.
} 
Ahhoz, hogy formálisan is rendben legyen a választás, és mindenhonnan legyenek jelöltek, Forgóék még arra is figyeltek, hogy Csanádpalotán, ahol a helyi viszonyok miatt addig nem jött létre nemzeti bizottság, elérjék annak megalakítását. Ez ügyben Forgó István VB-elnök személyesen kereste föl a községet és tárgyalt az érintettekkel. Dr. Horváth László állatorvos perében (aki a csanádpalotai forradalmi események központi alakja és utóbb a járási nemzeti bizottság megválasztott tagja lett) a tanúként beidézett Kurunczi Mihály helyi VB-elnök egyenesen azt vallotta, hogy „Az ö [ti. Forgó István - M. A.] és a pártbizottság közös utasitására kellett a Nemzeti bizottságot megalakitani. Azt mondták, hogy a járás többi községében már megalakultak a Nemzeti bizottságok, és még meg is szidtak azért, mert a mi községünkben még ezt nem alakitottuk meg." ${ }^{133}$ Mivel a nemzeti bizottság Forgóék ráhatására október 30-án a helyi tanács apparátusának lebonyolítói közremüködésével itt is megalakult, nem volt akadálya annak, hogy innen is érkezzenek küldöttek a járási nemzeti bizottsági választásra.

A november 3-án megtartott alakuló ülésen a járási tanács korábbi funkcionáriusai saját jelöltjeiket próbálták helyzetbe hozni. Mint Takács József a járási tanács titkárságvezetője, egyben Forgó VB-elnök egyik legközvetlenebb munkatársa egy későbbi per tanújaként elmondta: „A Városi Nemzeti Bizottság nyomására, vagyis utasitására javaslat alakult ki, hogy kiket válasszanak be a Járási Nemzeti Bizottság tagjai sorába. Így a választások alkalmával be lett választva Forgó István járási VB elnök, Sárvári Zoltán a járási pénzügyi osztály vezetője, Juhari Ferenc a pénzügyi osztály dolgozója, Pósa János a pénzügyi osztály dolgozója, valamint Kocsis Mihály pénzügyi dolgozó. Megjegyezni kívánom, hogy a fent felsorolt személyek mind párttagok voltak, vagyis jelenleg is párttagok." ${ }^{134}$ Azzal együtt, hogy a városi nemzeti bizottság ilyetén beavatkozása a járási nemzeti bizottság létrejöttébe és személyi összetételének alakításába (s ráadásul prominens kommunista jelöltek nevesítésével) teljességgel életszerütlen lett volna és nem is felelt meg a valóságnak (Takács ugyanis vallomásában nem a járási nemzeti bizottság, hanem a járási tanácsnál létrehozott „,kommunista eszmék iránt elkötelezett” munkástanács tagjait sorolta ${ }^{135}$ ), mégis a valószínűleg tudatalatti elszólása jól mutatja, hogy Forgóék a maguk oldaláról kikben gondolkodtak az új járási szerv vezetői pozícióiban.

Az, hogy a járási tanács kommunista vezetői saját szerepük megőrzése mellett képzelték el az új járási hatalmi szerv létrehozását, ismerve az MDP megyei vezetésének korábban kiadott állásfoglalását, miszerint a régi hatalom embereinek funkciókat kell szerezniük az újonnan megalakuló forradalmi szervekben, ${ }^{136}$ szinte biztosra vehető. A járási nemzeti bizottság választását a járási tanács vezetői úgy tervezték, hogy a községek - méretük alapján - különböző létszámú tagot delegálnak az új testületbe és a községeken kívül a járási tanács is 4 főt (a Takács József által említett elképzelések alapján föltételezhetően Forgót, Sárvárit, Juharit és Pósát) küld oda. ${ }^{137}$ A községi küldöttek azonban - keresztülhúzva a járási vezetők számítását - jóval radikálisabb

${ }^{133}$ MNL CSML SZL XXV. 9. SZMB B. I. 1211/1957. dr. Horváth László pere. Kurunczi Mihály tanúvallomása. A csanádpalotai helyzetről lásd bővebben MAROSVÁRI 2006. 36-49.

${ }^{134}$ ÁBTL 3. 1. 5. O-14943/100. Dr. Brenner József vizsgálati dossziéja. Takács József tanúkihallgatási jkv., 1957. július 11.

${ }^{135}$ MNL CSML ML 202. b. Makói Járási Tanács VB-elnökének iratai. 006/1957. Jelentés. 1957. március 9. 4.

${ }^{136}$ FARKas 2003. 213.; A Magyar Dolgozók Pártja Csongrád Megyei Bizottsága 1956. október 30-ai nyilatkozata. Közli: Viharsarok XII. évf. 257. sz. 1956. október 31. 2.

${ }^{137}$ MNL CSML ML 202. b. Makói Járási Tanács VB-elnökének iratai. 006/1957. Jelentés. 1957. március 9. 4. „,A munkástanács elgondolása a 4 fó járási tanács dolgozóival kapcsolatban az volt, hogy a vidéki nemzeti bizottsági tagok nehogy a járási dolgozókat elbocsássák. Ez a 4 fö megvédte volna a járási tanács dolgozóit az elbocsátástól, azonban erre nem került sor, mert a nemzeti bizottság ideje alatt elbocsátás nem történt.” MNL CSML ML 202. b. Makói Járási Tanács VB-elnökének iratai. 006/1957. Jelentés. Elökészitő anyag. 
követelésekkel álltak elő, mint azok gondolták volna, így az előzetes elképzeléseket nem voltak képesek keresztülvinni.

Amikor november 3-án délelőtt sor került Makón a járási tanács nagytermében a járási nemzeti bizottság megalakítására, Maroslele kivételével a járáshoz tartozó települések mindegyike delegáltak útján képviseltette magát. A 87 küldöttből 76 megjelent, így az ülés határozatképes volt. ${ }^{138} \mathrm{Az}$ előkészítést végző járási tanácsi munkástanács, pontosabban az ülést levezető Juhari Ferenc az előzetes terveiknek megfelelően javaslatot tett a bizottság összetételére és ismertette saját jelöltjeit, köztük megemlítette Forgó István VB-elnök nevét is. Forgó nevének elhangzását követően a küldöttek zúgolódni kezdtek, majd a jelen lévő elnököt több fölszólaló indulatos hozzászólásában, többek között az erőszakos termelőszövetkezetesítésben és tagosításban vállalt szerepéért, kemény hangú bírálatban részesítette. ${ }^{139}$ Ifj. Csipei Vilmos egyetemi hallgató, kiszombori küldött pl. ki is jelentette: ,nekünk nincs szükségünk ezekre a hat hetes gyorstalpaló tanfolyamokat végzettekre, van nekünk rendes egyetemet végzett ifjúságunk, akik el tudják végezni ezt a munkát. Ezek sztálinisták, rákosisták, ezeket ki kell söpörni [az] állásukból [...] Mi fiatalok nem azért harcoltunk, hogy restauráljunk, hanem hogy ujjat [sic!] épitsünk." 140 Hasonló hangnemben szólalt fel a Magyarcsanádról érkezett dr. Brenner József is, aki „erélyesen tiltakozott, hogy azok a személyek mind hüen kiszolgálták a Rákosi-rendszert és sztálinisták, azoknak a személyeknek semmi helyük sincs a nemzeti bizottságban". ${ }^{141}$ Forgó és a többi járási tanácsi funkcionárius jelölése ezt követően lekerült a napirendről, őket a teremből ki is küldték.

\footnotetext{
${ }^{138}$ A jelenléti ívet lásd: MNL CSML ML XXIII. 203. a. Makói Járási Tanács Titkársága iratai. 1-35/1956.

${ }^{139}$ MNL CSML ML 202. b. Makói Járási Tanács VB-elnökének iratai. 006/1957. Jelentés. 1957. március 9. 4.
}

${ }^{140}$ Csipeit utóbb e kijelentéséért másfél év börtönre ítélte az elsőfokú bíróság. Az indoklás szerint azért, mert ,,Vádlott kijelentéseinek társadalmi veszélyessége az ellenforradalmi eseményekre tekintettel igen súlyosak voltak és következményeiben terrorakcióra adhattak volna alkalmat. Azok ellen a munkás és paraszt káderek ellen izgatott [a] vádlott, akik a proletár hatalom bázisát képezik, valamint párttagok is és így személyükön keresztül nem csak a tanács, mint államigazgatási szerv, hanem a párt ellen is gyülöletet keltett.” MNL CSML SZL XXV. 9. SZMB B. I. 847/1957. Ifj. Csipei Vilmos pere. A Szegedi Megyei Bíróság B. I. 847/1957/4. számú itélete. Másodfokon viszont fölmentették, mivel a Legfelsőbb Bíróság szerint Csipei nem gyülöletet akart kelteni, hanem csak arra kívánta ráirányítani a figyelmet, hogy ,, a lehetöséghez képest mindenütt szakembereket alkalmazzanak.” A Legfelsöbb Bíróság Bf. VII. 3682/1957/10. számú itélete. Lásd még ÁBTL 3. 1. 9. V-142414. tanúvallomások 21-40., 49.; MNL CSML ML 202. b. Makói Járási Tanács VB-elnökének iratai. 006/1957. Jelentés. 1957. március 9. 4.; 006/1957. Jelentés. Elökészitő anyag. A másodfokú fölmentő ítélet bizonyosan szoros kapcsolatban állt azzal a ténnyel, hogy Csipeit 1958. október 3-án Szűcs Mihály r. hadnagy, a megyei rendőrkapitányság politikai nyomozó osztálya makói kirendeltségének tisztje - terhelő alapon - „Kovács Bertalan” fedőnévvel, ügynök minősítéssel beszervezte. Első kapcsolattartója Gyömbér György r. hadnagy volt. Bálint 2017. 55. Noha beszervezése ifjúságvédelmi területre szólt, a kiszombori nemzetőrség volt tagjait is vele figyeltették. Egy 1959-es állambiztonsági összefoglaló szerint „, A kiszombori »nemzetőrség« volt tagjai körében foglalkoztatni tudjuk »Kovács Bertalan « fn. [fedőnevü - M. A.] ügynökünket, aki maga is nemzetőr volt, így figyelemmel tudjuk kísérni a volt »nemzetőrök « jelenlegi tevékenységét.” ÁBTL 3. 1. 9. V-150367. Kimutatás a nemzetörség tagjairól. 87. 1960-ban egyházi vonalon is foglalkoztatni kívánták, Katona István klárafalvi (volt kiszombori) r. kat. segédlelkész megfigyelésére alkalmazták, de e tekintetben nem bizonyult megbízható hálózati személynek. Az akkor készült foglalkoztatási terve mindenesetre pontosan összefoglalja, a forradalomban kompromittálódó Csipeit eredetileg milyen területeken akarták foglalkoztatni, azaz mely területek álltak akkor az állambiztonsági szervek érdeklődése középpontjában: „Beszervezésekor feladatul kapta, hogy deritse fel Kiszombor községben azokat az ellenséges beállitottságú személyeket, akik rémhíreket terjesztenek a külföldi rádióadások alapján. Kísérje figyelemmel azokat, akik az ellenforradalom alatt tevékenykedtek. Az egyetemen feladatát képezi mindennemü ellenséges megnyilatkozás, antimarxista, soviniszta, antiszemita nézetek felderítése.” Az anyag egyébiránt rögtön negatív kitétellel folytatódott az »ügynöki« tevékenysége hatásfokát illetően: „A fenti feladatait mérsékelt eredménnyel és aktivitással elvégezte, illetve végzi." ÁBTL 3. 1. 5. O-12202/7. A dokumentumot fakszimilében közli: KAHLER (Vál. és szerk.) 2001. 96-99.

${ }^{141}$ ÁBTL 3. 1. 5. O-14943/100. Dr. Brenner József vizsgálati dossziéja. Takács József tanúkihallgatási jkv., 1957. július 11. 
Miként Forgó később írta: „, a [járási] nemzeti bizottság csúnya rágalmakkal illetve és rágalmazva a tanácsi dolgozókat is, hogy a munkás tanácsba [sic!] beválasztottak, kizavartak a tanácstól". ${ }^{42}$

Nyilván a Forgó személye kapcsán lefolyt vitának is köszönhetően az egybegyültek akként foglaltak állást, hogy a községek 1-1 képviselőjét, továbbá a járási tanács apparátusának egy jelöltjét választják meg. Ennek megfelelően állt össze a 16 tagból álló járási nemzeti bizottság, melynek elnöke Takács József, a volt makói járási tanács titkárságának vezetője lett, titkára dr. Brenner József magyarcsanádi tanár, a helyi Forradalmi Nemzeti Bizottság (FNB) tagja, tagjai pedig dr. Horváth László állatorvos a csanádpalotai FNB küldötte, Molnár János bérelszámoló a kövegyi FNB delegáltja, Fonyó Pál volt hivatásos katonatiszt a csanádalberti FNB tagja, Csipei Vilmos egyetemista a kiszombori FNB küldötte, Csontos János gazdálkodó az FKgP volt képviselője, a nagylaki nemzeti bizottság elnöke, Keresztúri András tanító az apátfalvi FNB tagja, Grósz János rákosi igazgató tanító, ${ }^{143}$ Simondán Márton földműves a királyhegyesi FNB elnöke, Krisztof András az ambrózfalvi FNB elnöke, valamint Rácz István kőműves a földeáki nemzeti bizottság elnöke lettek. ${ }^{144}$

Sajnos nem tudjuk, hogy az alakuló ülésen jelen lévő Óföldeák, Ferencszállás, Klárafalva, Pitvaros és Magyarcsanád kiket javasolt a járási nemzeti bizottság tagjai közé, miként azt sem, hogy a 11 ismert települési küldött és Takács József a járási tanács jelöltje, valamint a kimaradó 5 település választottja hogyan adta volna ki a 16 fős járási nemzeti bizottsági létszámot. Mivel forrásunk a választás menetével kapcsolatban nem maradt meg, elképzelhető, hogy a járási tanács delegáltján, Takács Józsefen kívül jelölhettek a települések, így a bizottság taglétszáma 16 + 1, azaz 17 fő lehetett. Föltételezhető, hogy ez valóban így lehetett, lévén, hogy a 16 fôs nemzeti bizottsági létszámkeretet egy 1959-es BM dokumentum határozta meg, egy olyan anyag, amely a járási tanács funkcionáriusáról, a bizottság elnökéről, Takács Józsefről még említés szintjén sem emlékezett meg $^{145}$ és utóbb ellene semmiféle eljárást nem indítottak, alátámasztva ezzel is, hogy ő valóban a régi, majd november 4. után ismét hatalomra került rendszer embere volt.

Az esemény súlyát jelezte, hogy a járási nemzeti bizottság alakuló ülésén megjelent a régi hódmezővásárhelyi szociáldemokrata Erdei István is, aki október 31. óta a Csongrád Megyei Ideiglenes Nemzeti Bizottság elnöki tisztét töltötte be. Fölszólalásában a pártok újjászervezésének fontosságára és a helyi politikai életbe történő bekapcsolódásuk szükségességére hívta föl

${ }^{142}$ MNL CSML SZL XXXIII. 3. MSZMP Archívuma. 9. Az MSZMP Makó Városi Bizottsága iratai. Személyi anyagok 1957-1989. Forgó István dossziéja. Önéletrajz, 1958. április 11.

${ }^{143}$ A járási nemzeti bizottság tagjai közül - a rendelkezésünkre álló adatok alapján - Csipei Vilmos mellett 1958. május 15-én az akkor közbiztonsági őrizetben lévő Grószt is - terhelő alapon - beszervezte a politikai elhárítás egyik tisztje, amely elől nem tudott kitérni. Fedőneve „, Garamvölgyi”, foglalkoztatási vonala börtönelhárítás volt, ami azt jelentette, hogy az ugyancsak őrizetben lévő társairól kellett jelentenie. Miután közbiztonsági őrizete 1958. július 17-ével megszünt, e kényszerű kötelezettségétől meg tudott szabadulni, bár az állambiztonsági hálózatból csak 1962 októberében bocsátották el véglegesen. BÁLINT 2017. 85.; ÁBTL 3. 1. 5. O-14967. 19.

${ }^{144}$ A Makói Járási Nemzeti Bizottság tagjait rögzítő dokumentum, melyet a BM Csongrád Megyei Rendőrkapitányság Politikai Nyomozó Osztálya Összefoglaló a forradalmi bizottságokról címmel 1959-ben készített, csupán 11 nevet sorolt föl és jelezte, hogy ,, a fentieken kivül még 5 tagja [volt], ezek a személyek nem fejtettek ki emlitésre méltó tevékenységet". A dokumentumban néven nevezett személy dr. Brenner József, dr. Horváth László, Fonyó Pál, Csipei Vilmos, Keresztúri András, Molnár János, Csontos János, Grósz János, Simondán Márton és Krisztof András, továbbá Rácz Imre igazgató-tanító, aki viszont biztosan nem volt tagja a nemzeti bizottságnak. Lásd ÁBTL 3. 1. 9. V-150355/2. 32-34. Egy másik 1959-ből származó BM összeállítás a tizenhat tagból hármat nevesít: Takács Józsefet, a járási nemzeti bizottság elnökét, valamint Horváthot és Molnárt, akik az előző listán is szerepeltek. FEJÉR 2009. 129. Lásd még MAROSVÁRI 2006. 178-181.

${ }^{145}$ Lásd: ÁBTL 3. 1. 9. V-150355/2. Összefoglaló a forradalmi bizottságokról. 32-34. 
a jelenlévő nemzeti bizottsági képviselők figyelmét. Mivel másnapra, november 4-ére tervezték a végleges megyei nemzeti bizottság megválasztását Hódmezővásárhelyen, az ezen való részvételre is kérte és buzdította a megjelenteket. ${ }^{146}$ Erre az ülésre azonban a szovjet intervenció megindulása következtében megváltozott körülmények miatt már nem került sor.

A járási nemzeti bizottság a járási tanács helyét foglalta el, míg az intéző bizottság (melynek összetételéről nem maradt adatunk, föltételezhetően nem is alakult meg) a járási VB feladatköreit vette volna át. ${ }^{147} \mathrm{~A}$ járási nemzeti bizottság az alakuló ülést követően érdemi munkát a november 4-ei szovjet beavatkozás miatt már nem fejtett ki, ülést nem tartott, döntéseket nem hozott, noha a bizottság vezetői november 8-áig még bizonyosan helyükön voltak. A járási nemzeti bizottság rendelkezésére álló néhány nap történéseit az utóbb büntetőeljárás alá vont dr. Brenner József a bizottság titkára vallomása alapján rekonstruálhatjuk: ,,1956. november 3-án átvettem a hivatalomat és velem együtt az elnök és helyettesei is ${ }^{148}$ Ez alkalommal összehívtuk a tanácsi dolgozókat, ahol én és az elnök egy rövid beszédet mondottunk, melyben megnyugtattuk a dolgozókat, hogy elbocsátás nem lesz, mindenki maradjon a helyén és végezze a dolgát. Elosztottuk a reszortokat magunk között oly formában, hogy patronáltuk, illetve ellenöriztük az egyes osztályokat. Én a pénzügyi, oktatási, igazgatás-rendészeti osztályt és a titkárságot ellenőriztem. Egy alkalommal voltunk mindössze kint a járás községeiben, ez alkalommal a szesztilalom, a közellátás és a fegyverek összeszedése, valamint a befolyt adózási pénzek ügyében jártunk kint. Foglalkoztam továbbá az iskolák helyzetével és tüzrevaló-problémákkal, amiket igyekeztem megoldani." ${ }^{49}$

Mint a városi nemzeti bizottság esetében, úgy a járási nemzeti bizottság esetében is részleges sikert ért el az MDP hatalomátmentési kísérlete. Míg ott annyiban értek el sikert, hogy meg tudták akadályozni a radikális elképzelésekkel bíró és ezzel esetlegesen rájuk veszélyt jelentő tagok beválasztását a nemzeti bizottságba és el tudták érni, hogy a bizottság élére olyan volt koalíciós politikusok kerüljenek, akikkel meg tudták találni a közös hangot és akiket esetleg később mögöttes alkukkal irányítani is tudtak volna, addig a járási nemzeti bizottságban azt tudták elérni - és ez abban a helyzetben egyáltalán nem volt kevés -, hogy a bizottság elnöke Takács József, Forgó István volt járási VB-elnök egyik legközvetlenebb és leghűségesebb munkatársa lett, hiszen a járási tanács azon vezető állású beosztottai közé tartozott, akikkel a forradalom első napjaiban Forgó dokumentálható módon is rendszeresen konzultált a tennivalókat illetően. Forgó másfél évvel később így írt erről: noha őt és több társát nem sikerült megválasztatnia, sőt a tanácstól is elküldte az új járási nemzeti bizottság, „,Még az utolsó pillanatban is nekem sikerült megoldani, hogy a nemzeti bizottságba Takács elvtárs bekerüljön, majd ez lett [sic!] annak elnöke, ami jó volt. Különben a Gervai elvtárssal [a járási pártbizottság akkor még elérhető munkatársával - M. A.] ezt elötte megbeszéltem, illetve ő mondta, hogy vigyázzak és amit lehet, tegyek meg." "150 Takács személye tehát - legalábbis egy ideig - garancia lett volna arra, hogy egyetlen olyan döntés ne születhessen, amelyről Forgó (és a kommunista pártapparátus) ne tudott volna, vagy amivel ne értett volna egyet. A járási tanács vezetőinek szándéka tehát,

\footnotetext{
${ }^{146}$ BÁlint 2003. 83.

${ }^{147}$ ÁBTL 3. 1. 5. O-14943/100. Dr. Brenner József vizsgálati dossziéja. Dr. Brenner József gyanúsitott kihallgatási jkv., 1957. július 17.

${ }^{148}$ Arról, hogy kiket választottak a járási bizottság elnökének helyetteseivé, adattal nem rendelkezünk.

${ }^{149}$ ÁBTL 3. 1. 5. O-14943/100. Dr. Brenner József vizsgálati dossziéja. Dr. Brenner József gyanúsitott kihallgatási jkv., 1957. július 17 .

${ }^{150}$ MNL CSML SZL XXXIII. 3. MSZMP Archívuma. 9. fond. Az MSZMP Makó Városi Bizottsága iratai. Személyi anyagok 1957-1989. Forgó István dossziéja. Önéletrajz, 1958. ápr. 11.
} 
hogy ellenőrzésük alá vonják az új hatalmi szervet, ha nem is teljesen, de mégiscsak sikerült. Idő azonban már nem volt arra, hogy Takács e pozícióban kipróbálhassa magát és bizonyíthassa így is a megbízói iránti elkötelezettségét.

Ahogy említettük, a járási nemzeti bizottság az alakuló ülést követően nem tartott újabb ülést, így nem tudjuk, milyen elképzelések szerint szervezték volna újjá a járás településeinek együttműködését, miként arról sincs semmiféle információnk, milyen kapcsolat létesült volna a járási tanács volt vezetői és funkcionáriusai, köztük Forgó István, illetve az új néphatalmi szerv tagjai között. Erre a rendelkezésre álló rövid idő alatt semmiféle adat nem képződött, de szinte biztosra vehető, hogy a forradalom nagyobb kifutása esetén ez a kétélü helyzet komoly konfliktusokat generált volna.

\section{ÖSSZEGZÉS}

Az 1956-os forradalom idején Makón létrejövő új helyi hatalmi szervek mind megszületésük körülményei, mind pedig müködésük megszervezése tekintetében szinkronban voltak az országos tendenciákkal, bár némi (1-2 napos) fáziseltolódásra felfigyelhetünk. A városi tanács feladatait itt is az 1945-ös mintát követően létrehozott nemzeti bizottság gyakorolta, s szervezésére is a koalíciós gyakorlatnak megfelelően népfrontos jelleggel került sor, azaz a szervezők azt szerették volna elérni, hogy minden demokratikus párt kapjon helyet benne. Mivel a nemzeti bizottság létrehozói közül kimaradtak a radikális politikusok (ilyenek nem is nagyon voltak Makón), az alapítók az egykori pártok mérsékelt személyiségei közül kerültek ki, akik igazából nem is akartak ,rendszerváltozást” a forradalommal, csupán az 1948 előtti többpárti koalíciós viszonyokat szerették volna helyreállítani. Jól mutatja ezt a megközelítést a nemzeti bizottság megalakítására az MDP funkcionáriusai által kezdeményezett és október 28-án megkötött politikai alku, melyben a kommunisták által fölkínált együttműködést elfogadva az SZDP és az FKgP megjelent képviselői koalíciós partnerként, tehát - mint ezt Kiss Ernő, a létrejövő nemzeti bizottság szociáldemokrata alelnöke október 31-én egy vita közben meg is erősítette gyakorlatilag demokratikus pártként fogadták el a Rákosi-rendszer állampártját, az MDP-t. Igazából tehát a népakarat és nem a (párt)politikai akarat volt a döntő abban, hogy az október 29-ei népfrontos választás kudarcra ítéltetett, és október 30-án már az MDP tagjai nélkül jött létre az új városi hatalmi szerv.

Az MDP aktivistái az első napokban fékezni igyekeztek a forradalom elharapózását, majd amikor ezt már nem tudták érdemben megakadályozni (október 26-27.), akkor a legfőbb törekvésük volt, hogy az újonnan létrejövő szervezetekbe bekerüljenek, illetve azokat irányításuk alá vonják. E célt szolgálta az a nem ritka, de általánosnak egyáltalán nem tekinthető lépésük, hogy éppen ők voltak azok, akik Makón a nemzeti bizottság megalakítását operatív pártközi egyeztetés összehívásával kezdeményezték, és e lépésükkel nem csupán az új néphatalmi szerv létrehozásának kezdeményezői lettek, hanem egyúttal az egykori koalíciós pártok föltámasztásának elősegítői is, hiszen ezt megelőzően e pártok vagy vezetőik megjelenésére vagy ténykedésére vonatkozóan semmiféle adat nem utal.

A nemzeti bizottság tevékenysége a forradalom és szabadságharc napjaiban igazából minimálisnak és formálisnak volt tekinthető, s az abban részt vevő irányító szerepet betöltő politikusok (elsősorban az SZDP, de valamilyen mértékben az FKgP képviselői is) inkább fékezni akarták, mint radikalizálódni engedték volna az eseményeket. Az általuk támogatott lépések elsősorban a közellátás folyamatosságának biztosítására koncentráltak, valamint arra, hogy a pártok és 
szervezetek elhelyezési problémáit a volt irodák visszaadásával megoldják, de nem irányultak a meglévő rendszer alapvető átalakítására, ezt jól mutatta például, hogy a városi tanács apparátusa a tömegakarat elvárása ellenére változatlan összetételben bizalmat kapott tőlük. A nemzeti bizottság nem támogatott semmiféle a kollektív tulajdon fölszámolására és az egykor erőszakkal állami tulajdonba vett termőföldek és vagyontárgyak visszaszolgáltatására vonatkozó - a tömegtüntetéseken egyébként megfogalmazódó - törekvést sem, amíg annak törvényes föltételei nem teremtődtek meg.

A nemzeti bizottság vezetői a kommunista állampárt árnyékától sem tudtak megszabadulni, amely a bizottság létrehozásának október 28-ai kezdeményezésétől kezdve a fejük fölött lebegett. A szakítás jelképes gesztusa lehetett volna az MDP iratanyagának „,lepecsételésére” irányuló javaslat, amelyet kisebb vita után el is fogadtak, de ezt a döntést aztán az ezért felelőssé tett Fazekas Lajos rendőrkapitány - a határozatot szándékosan és tudatosan bojkottálva - nem hajtotta végre. Fazekas e lépésével egyértelmüen hozzájárult ahhoz, hogy a nagy tömegmozgalmak időszakának lezárulását követően az MDP-funkcionáriusok sértetlenül és többé-kevésbé zavartalanul vészelhették át a forradalom hátralévő napjait, és a háttérben folyamatosan dolgozhattak azon, hogyan és mikor foglalhatják vissza megingott pozícióikat. Erre azután néhány nap elteltével, a szovjet intervenció oldalvizén sor is kerülhetett. Korábbi megkérdőjelezhetetlen és kizárólagos vezető pozíciójukat visszafoglalva aztán a kommunisták már nem voltak olyan mértéktartóak és kíméletesek, amiként velük szemben a forradalom napjaiban a városi nemzeti bizottság vezetői viselkedtek, s karhatalmistáik, valamint az általuk irányított rendfenntartó és igazságszolgáltatási szervek révén gondoskodtak róla, hogy soha senki ne feledkezzen meg arról, amit akkor, a forradalom napjaiban a kommunista állampárti berendezkedés megkérdőjelezésével ellenükre tett.

\section{BiBLIOGRÁfia}

\section{Levéltárak}

ÁBTL: Állambiztonsági Szolgálatok Történeti Levéltára

JAM TD: József Attila Múzeum Történeti Dokumentációs Gyűjtemény

MNL CSML ML: Magyar Nemzeti Levéltár Csongrád Megyei Levéltár Makói Levéltára

MNL CSML SZL: Magyar Nemzeti Levéltár Csongrád Megyei Levéltár Szegedi Levéltár

\section{Felhasznált irodalom}

Antal Tamás (2009): A tanácsrendszer és jogintézményei Szegeden (1950-ss1990). Szeged, Csongrád Megyei Levéltár.

BALOGH SÁNDOR (főszerk.) (1993): A Magyar Szocialista Munkáspárt ideiglenes vezető testületeinek jegyzőkönyvei. I. kötet. 1956. november 11-1957. január 14. Budapest, Intera Rt.

BÁlint LÁszló (1996): 1956. A forradalom Szegeden és Csongrád megyében. Szeged, Magyarok Világszövetsége 1956-os Bizottsága.

BÁlint LÁszló (2003): 1956 Hódmezővásárhelyen. Hódmezővásárhely, Hódmezővásárhely Megyei Jogú Város Polgármesteri Hivatal. 
BÁlint LÁszló (2006): 1956. A forradalom Makón. Szeged, Móra Ferenc Múzeum Múzeumi Tudományért Alapítványa.

BÁLINT LÁszLó (2017): A hálózati nyilvántartás szereplői. Az államvédelmi és állambiztonsági hálózat nyilvántartása Szegeden és Csongrád megyében (Töredék). 1945-1990. [Budapest].

Blazovich LÁszLó (szerk.) (2007): Csongrád megye tanácsainak tisztségviselői. (1950-1990). Szeged, Csongrád Megyei Levéltár.

FARKAS CsABA (2003): Csongrád megye. In Szakolczai Attila és Á. Varga László (szerk.): A vidék forradalma 1956. I. Budapest, 1956-os Intézet - Budapest Főváros Levéltára. 201-232.

FARKAS CsABA (2006): Hatalomváltás Csongrád megyében 1956-ban. Aetas 21. évf. 1. sz. 100-108. FAzeKAs JÁnOs (2016): Visszaemlékezés. In J. Balog Tünde (szerk.): Emlékkönyv az 1956-os forradalom 60. évfordulójára. Makó, József Attila Városi Könyvtár és Múzeum.

FEJÉR DÉNES (szerk.) (2009): „,Monográfia”. Az 1956-os forradalom és szabadságharc eseményeiről és szereplőiről Csongrád megyében rendőri (állambiztonsági) szemmel. Szeged, Bába Kiadó.

IzSÁK Lajos (főszerk.) (1998): A Magyar Dolgozók Pártja határozatai 1948-1956. Budapest, Napvilág Kiadó.

KAHLER FrIGYES (vál. és szerk.) (2001): III/III-as történelmi olvasókönyv. Adalékok az emberi jogok magyarországi helyzetéhez az 1960-as években. A „, vallásszabadság”. Budapest, Kairosz Kiadó.

KATONA SÁNDOR (é. n.): Történelmi sorsforduló. Kézirat. Lelőhely: MNL CSML SZL XXXIII. 3. MSZMP Archívum. 52. A munkásmozgalom megyei résztvevőinek iratai. 3. ő. e. Visszaemlékezések.

KoROM MinÁly (szerk.) (1981): Makó az első felszabadult magyar város. A szocializmus alapjai lerakásának történetéhez. Makó, Makó Város Tanácsa VB Müvelődésügyi Osztály.

LANTOS PÉTER (2009): Sínek és sorsok. Budapest, 2009. Scolar Kiadó

MARosvÁRI ATTILA (2006a): Kik és hogyan döntötték le 1956-ban a makói szovjet emlékművet? Marosvidék VII. évf. 2. sz. 3-7.

Marosvári Attila (2006b): 1956. Forradalom és restauráció a Makói járás falvaiban. Makó, Csongrád Megyei Múzeumok Igazgatósága - Múzeumi Tudományért Alapítvány.

MAROSVÁRi ATtila (2008): Munkástanácsok Makón az 1956-os forradalom idején. In Forgó Géza (szerk.): Szirbik Miklós léptein... Tanulmányok Halmágyi Pál 60. születésnapjára. Makó, József Attila Múzeum. 145-150.

MARosvÁRI ATTILA (2017): Szempontok az 1956-os makói forradalom eseménytörténetének értelmezéséhez. Kézirat.

MeZey BARNA (szerk.) (1995): Magyar alkotmánytörténet. Budapest, Osiris Kiadó.

Mikó Zsuzsanna (2016): A terror hétköznapjai. A kádári megtorlás 1956-1963. Budapest, Libri Könyvkiadó.

MüLlER VeronIKA (főszerk.) (1988): A tanácsigazgatás szervei 1950-1970. Budapest, Közgazdasági és Jogi Könyvkiadó. 
Solt PÁL et al. (szerk.) (1995): Iratok az igazságszolgáltatás történetéhez. 4. kötet. Budapest, Közgazdasági és Jogi Könyvkiadó.

SzENTPÉTERI IMRE (1981): A közigazgatás a szocialista átalakulás útján. In Korom Mihály (szerk.) (1981): Makó az elsö felszabadult magyar város. A szocializmus alapjai lerakásának történetéhez. Makó, Makó Város Tanácsa VB Művelődésügyi Osztály. 63-96.

TAMASI MiHÁLY (1974): A népi demokratikus forradalom győzelme. In Korom Mihály (szerk.) (1974): Makó az elsö felszabadult magyar város. II. kötet. A népi demokratikus forradalom győzelme. Makó, Makó Városi Tanács. 37-162.

TAMASI MiHÁly (1981): A szocialista építés kibontakozása és Makó társadalmi-politikai életének fejlődése 1948-1962 között. In Korom Mihály (szerk.) (1981): Makó az első felszabadult magyar város. A szocializmus alapjai lerakásának történetéhez. Makó, Makó Város Tanácsa VB Művelődésügyi Osztály. 1981. 5-62.

TóTH FERENC (1992): Az 1956-os forradalom kezdete és következményei Makón. Makó, Keresztény Értelmiségiek Szövetségének Makói Csoportja.

TóTH FERENC (szerk.) (1996): Az 1956-os forradalom Makón a dokumentumok tükrében. Makó, Szirbik Miklós Társaság.

Tóth FERENC (2006): Az '56-os forradalom egy napja Makón. In Bálint László (2006): 1956. A forradalom Makón. Szeged, Móra Ferenc Múzeum Múzeumi Tudományért Alapítványa. 123-126.

URBANCSOK ZsOLT (2018): Makói zsidó polgársors. Szemere (Schwarz) Manó élete és tevékenysége. In Csengeriné Szabó Éva et al. (szerk.): József Attila Múzeum évkönyve II. Makó. 147-165.

VARGA LÁszLó (összeáll.) (1989): A forradalom hangja. Magyarországi rádióadások 1956. október 23-november 9. Budapest, Századvég Kiadó és a Nyilvánosság Klub.

VARGA ZsUZSANNA (2006): Paraszti követelések 1956-ban. In Estók János (szerk.): 1956 és a magyar agrártársadalom. Budapest, Magyar Mezőgazdasági Múzeum. 81-104.

VIDA IsTVÁN (főszerk.) (1994): Az 1944. évi december hó 21-re Debrecenbe összegyült, majd később Budapestre összehívott Ideiglenes Nemzetgyülés almanachja. 1944. december 21. 1945. november 29. Budapest, Oktáv-Press Kiadó.

VIDA IsTVÁN (szerk.) (1998): 1956 és a politikai pártok. Politikai pártok az 1956-os forradalomban 1956. október 23-november 4. Válogatott dokumentumok. Budapest, MTA Jelenkor-kutató Bizottság. 